\title{
CONSIDERAÇÕES PRELIMINARES SOBRE O MODO DE SER DA IDEIA NA METAFÍSICA DE SCHOPENHAUER
}

\section{PRELIMINARY CONSIDERATIONS ON THE IDEA'S WAY OF BEING IN SCHOPENHAUER'S METAPHYSICS}

\author{
Dax Moraes ${ }^{1}$
}

Recebido em: 02/2018

Aprovado em: 03/2018

\begin{abstract}
Resumo: O presente artigo traz algumas observações acerca do problema ontológico encontrável na teoria schopenhaueriana das Ideias, a saber, seu duplo e mesmo "contraditório" caráter de serem, a um só tempo, universais e eternas, individuadas e determinadas enquanto produzidas mediante a luta da Vontade consigo mesma. Deve-se conferir às Ideias um papel metafísico e não apenas epistêmico? Como e por que são múltiplas e em que sentido? Deve-se considerá-las como um terceiro ao lado ou entre Vontade e Representação? A fim de se solucionar semelhantes problemas não basta refletir sobre o conhecimento das "Ideias platônicas" enquanto objetos, mas compreender o seu papel segundo seu peculiar significado, bem como sob uma forma meramente relativa de eternidade. Para tanto, parto de uma acurada consideração acerca do segundo livro da obra capital de Schopenhauer, no qual a Ideia é primeiramente apresentada como uma entidade metafísica, do que deve se seguir inesperadas consequências no que diz respeito à Filosofia de Natureza e mesmo à Ética schopenhauerianas.
\end{abstract}

Palavras-chave: Vontade; Natureza; Ideia; Espécies; Objetivação.

\begin{abstract}
This paper offers some remarks on the ontological problem of the Schopenhauer's theory of Ideas, i.e. their double and even "contradictory" character of being at once eternal, universal, and on the other hand individuated and determined as produced by the struggle of the Will against itself. Should the Ideas really have a metaphysical role, not a simple epistemic one? How can them be plural and why and what that really means? Should we take them as a third besides or between Will and Representation? For the sake of solving such problems it is not enough a reasoning on the knowledge of "Platonic Ideas" as an object. We must instead comprehend the role of Ideas under a peculiar meaning and a mere relative kind of eternity as well. This can be done initially by the means of a careful consideration on the second book of Schopenhauer's main work, in which he brings out the Idea as a metaphysical entity for the first time. It would follow unexpected consequences concerning Schopenhauer's Philosophy of Nature and even his Ethics.
\end{abstract}

Keywords: Will; Nature; Idea; Species; Objectivation.

\footnotetext{
${ }^{1}$ Doutor em Filosofia. Professor Adjunto no Departamento de Filosofia e membro permanente do PPGFIL da Universidade Federal do Rio Grande do Norte.
} 
Grande parte dos estudos em torno da teoria schopenhaueriana das Ideias se concentra nos temas sugeridos pela Metafísica do Belo. Com efeito, é ali que as Ideias desempenham seu pleno papel de objeto privilegiado, uma vez consistindo em objetidades imediatas da Vontade. A obscuridade começa precisamente quando se busca compreender o status ontológico dessa representação sui generis, a Ideia como objetidade imediata, portanto, o que lhe confere tamanha dignidade na ordem do mundo do conhecimento, bem como ao sujeito capaz de intuí-la. Todavia, justamente por isso, importa esclarecer o modo de ser das Ideias, ou seja, seu papel enquanto objetidades da Vontade. Muitas vezes, a discussão a respeito se restringe à polêmica em torno do caráter efetivamente platônico (ou não) das Ideias. Não é, contudo, objetivo do presente artigo aprofundar essa questão em particular, mas deter-se no momento em que Schopenhauer, em sua obra capital, $O$ mundo como vontade e representação (MVR), tematiza pela primeira vez a natureza e o papel das Ideias, com destaque para os $\S \S 26-28$ do primeiro tomo, ainda no contexto da Filosofia da Natureza, o primeiro livro que aborda a perspectiva do mundo como Vontade.

A própria determinação da Ideia como "platônica" ocorre um pouco mais acima, no $\S 25$, e, de acordo com essa passagem, assumo metodologicamente o seguinte significado, independente do fato de as Ideias, em Schopenhauer, serem ou não sob algum aspecto o mesmo que eram em Platão: por "platônica", Schopenhauer pretende distinguir sua própria concepção daquela vigente na modernidade, de maneira a resgatar seu sentido de entidade autônoma (e preexistente) com relação ao intelecto, por isso independente do princípio de razão suficiente e mesmo, em sentido estrito, do princípio de individuação. ${ }^{2}$ Veremos adiante por que isso produz um (ou mais) problema(s) interpretativo(s) de que deverei me ocupar aqui. Isso considerado, buscar remeter a Ideia schopenhaueriana à platônica, como deverá ficar claro ao longo da exposição, tende mais a obscurecer do que solucionar os problemas, muitas vezes decorrentes dessa identificação reiterada exaustivamente pelo próprio

\footnotetext{
${ }^{2}$ A demarcação mais exata do sentido ontológico das Ideias em sua relação com o mundo sensível ocorre no MVR I, §41 (final), quando Schopenhauer chega a divergir de Platão e da consequência crucial de sua doutrina no que diz respeito ao valor da arte e o que ela representa. Isso à parte, é controversa e delicada a afirmação de que as Ideias preexistem em relação ao intelecto, o que pode ser compreendido de modo ambíguo: as Ideias têm existência real independente de todo intelecto ou são meramente conhecidas como universais de aparências particulares que, no tempo e no espaço, precedem todo organismo inteligente? Neste artigo, assumo a segunda interpretação, conforme justificativas que apresentarei em momento oportuno da exposição. A autonomia das Ideias, nesse caso, quereria dizer que, em seu caráter objetivo, não são produtos do intelecto, tampouco formas existentes no intelecto, mas aquilo que a Vontade visa objetivar, ou seja, por assim dizer, a direção de seu esforço.
} 
Schopenhauer. Em outras palavras, a teoria schopenhaueriana das Ideias será abordada a partir dela mesma, no contexto preciso em que essa teoria emerge em sua obra capital. A referida passagem é a seguinte:

[...] os graus de objetivação da [V]ontade, ia dizer, não são outra coisa senão as ideias de Platão. [...] a palavra ideia [...] deve em minha obra ser entendida na sua significação autêntica e originária, estabelecida por Platão, e de modo algum se deve pensar com ela nas produções abstratas da razão escolástica dogmatizante, para cuja descrição Kant usou tão mal como ilegitimamente a referida palavra [...]. (SCHOPENHAUER, 2015a, §25, p. 151)

Vale observar que o mencionado uso "ilegítimo", isto é, "dogmático", é precisamente aquele empregado pelo Idealismo alemão, sobretudo por Fichte. O próprio Kant fez uso do termo para se referir a pretensos objetos puros da razão, como Deus, alma, mundo, e também liberdade etc., um mau uso que Schopenhauer diz, em seguida, não levar em consideração. É certamente tendo em vista esse extravio que Schopenhauer, sem contradição, em clara alusão aos sistemas da época, coloca a palavra "ideia" dentre outros "sons vazios", tais como “absoluto" e "infinito" (SCHOPENHAUER, 2014, cap. 28, p. 508; 2015b, p. $423^{3}$ ).

\section{O problema metafísico e algumas propostas de solução}

O problema metafísico da teoria schopenhaueriana da Ideia é exposto por Roger (2013, p. 34) no verbete que lhe é consagrado em seu Vocabulário de Schopenhauer, problema esse que ele termina dizendo consistir em um mistério que não se pode resolver (!): "Como explicar, então, que ela [a Vontade] se pluralize em objetidades imediatas, se estas continuam independentes do Princípio de Individuação, que está na origem da diversidade fenomênica?”. É especialmente este problema que pretendo investigar aqui e para cuja discussão considero incontornável recorrer ao que se lê nos $\S \S 26-28$ do MVR. Para resolvê-lo, alguns estudiosos apelam para a noção de uma "ponte" entre o mundo como vontade e o mundo como representação. É o que faz, por exemplo, Pernin (1995, p. 110; grifo meu):

\footnotetext{
${ }^{3}$ Nas citações de traduções do MVR II serão utilizadas tanto a versão de Eduardo Fonseca (2014) quanto a de Jair Barboza (2015b). A eventual opção por uma ou outra, bem como minhas modificações pontuais, se baseiam no cotejamento da edição alemã de 1877 .
} 
É difícil compreender o status da Ideia para Schopenhauer, pois ele é um tanto híbrido: pura representação ainda incluída em uma forma fenomenal mínima, a mais geral, a da correlação sujeito/objeto, a Ideia é também qualificada de essência em si, porque é a objetivação mais imediata da [V]ontade. Essa ponte entre os dois mundos da representação e da vontade é frágil, do ponto de vista da inteligência discursiva.

Ora, parece ser precisamente essa "fragilidade" que atrai mais o interesse e, desse modo, impõe um extravio. De fato, o papel de "ponte" é anunciado pelo próprio Schopenhauer já no Livro II do MVR, mas apenas na medida em que a Ideia deve ser estimada como correlato inteligível (universal) dos fenômenos sensíveis (particulares) cuja elucidação última só pode ser oferecida por uma metafísica, jamais por uma ciência positiva da Natureza. Nesse sentido, as Ideias como que preenchem uma lacuna necessária para que se salte da Física para a Metafísica. Todavia, esse papel epistêmico é aquele que devemos aqui deixar de lado em prol de uma abordagem de caráter ontológico, o que, por sua vez, não significa que esse caráter "híbrido" da Ideia não produza impasses também na compreensibilidade da ontologia schopenhaueriana. Em atenção a isso, faz-se necessário penetrar um pouco mais nessa controvérsia. A abordagem de Shapshay (2012) parece mais completa: as Ideias não se encaixariam bem em nenhum dos dois modos de consideração do mundo, embora pareça pertencer ora a um, ora a outro, do mesmo modo que ora parece incompatível com um, ora com outro. O que se deve observar antes de tudo é que, a cada vez que a Ideia é apresentada por Schopenhauer como compatível com a ordem das coisas-em-si, isso se dá por ela ser alheia e mesmo independente do princípio de razão suficiente, sendo apenas do ponto de vista de sua cognoscibilidade, exposta no Livro III do MVR, que se torna marcante sua distinção com relação à coisa-em-si enquanto objeto de uma "inteligência" extraordinária. Apesar disso, em vez buscar ir mais fundo no modo de ser da Ideia, em que sentido ou de que a Ideia seria uma "essência em si", Shapshay toma o caminho mais usual mediante a colocação de uma segunda dificuldade, a mesma já referida acima nas palavras de Roger:

[Schopenhauer] frequentemente se refere às Ideias no plural. Para Schopenhauer, espaço e tempo são o principium individuationis; mas sendo as Ideias independentes de espaço e tempo, não fica de modo algum claro como elas podem ser individuadas. Uma opção para se compreender o lugar das Ideias em seu sistema seria vê-las como desempenhando o papel de uma ponte epistêmica ao invés de uma ponte metafísica entre a vontade única e os muitos fenômenos. (SHAPSHAY, 2012) 
Ou seja, em vez de buscarem aprofundar a compreensão acerca do modo de ser da Ideia, os estudiosos aqui elencados a título de exemplo privilegiam o que se pode dizer a seu respeito a partir de seu modo de representação, o que significa negligenciar a dimensão ontológica - expressamente descartada por Shapshay - que pela via epistêmica se busca não mais que traduzir, tanto quanto possível. ${ }^{4}$ Em verdade, considerar as Ideias como "ponte" termina por produzir uma ponte para se evadir do problema. Muito embora o autor se refira às Ideias frequentemente no plural, deve-se atentar para as ocasiões em que o faz, bem como para as ocasiões em que se refere à Ideia, no singular, a despeito de Schopenhauer não ser o melhor exemplo de rigor terminológico. Não é à toa que, nesse caso, a questão pareça insolúvel. Mas eis o que, segundo Shapshay, ajudaria a explicar a metáfora schopenhaueriana segundo a qual as Ideias seriam como degraus de uma escada no avanço da Vontade expresso em objetidades cada vez mais perfeitas. Haveria, para Shapshay (2012), um duplo modo de conceber as Ideias: uma Ideia universal (a escada) como parte do mundo como representação e uma diversidade de Ideias (os degraus) como universais enquanto "percebidos em vários objetos espaço-temporais particulares". Não se pode negar que se trata de uma engenhosa forma de dar sentido à aparente inconsistência da doutrina de Schopenhauer, mas tal engenho parece apenas requerido por um pressuposto enganoso, a saber: que a via epistêmica seja autossuficiente. Ademais, a concepção de uma Ideia das Ideias, um universal dos universais, parece contrariar questões de princípio do pensamento schopenhaueriano, mais fundamentais do que aquelas que servem de base para se apontar a inconsistência. Isso fica claro quando Shapshay se deixa levar a uma conclusão que, a meu ver, destruiria todo o projeto filosófico de Schopenhauer de oposição ostensiva ao idealismo alemão ${ }^{5}$, ou seja, tomar esse objeto eterno como uma realidade absoluta, portanto, independente de um sujeito. Diz ela:

\footnotetext{
4 “Tradução" é o termo empregado também por Cacciola (1994, p. 79-80). Retornarei a isso em breve.

5 Assumo aqui, sem discussão, a oposição genérica de Schopenhauer aos idealistas de seu tempo - Fichte, Schelling e Hegel - por razões pragmáticas. Uma adequada discussão é, todavia, não apenas relevante, mas necessária, tanto quanto extensa e intrincada, já que os quatro pensadores divergem entre si em pontos importantes, não podendo ser reduzidos um ao outro sem injustiça. O próprio tratamento dado por Schopenhauer a cada um diverge eventualmente. A polêmica contra Fichte é muito clara e bem fundamentada na obra de Schopenhauer, mas o oposto se dá no que tange à filosofia de Hegel, com relação à qual o primeiro praticamente se limita às ofensas ou acusações de ininteligibilidade. Neste artigo, entretanto, aponta-se que a relação é problemática, e ainda, que Hegel talvez não fosse tão ininteligível para Schopenhauer quanto este alegava, tornando-se curiosa sua evasão de um debate mais aberto e substancial. Talvez, uma aproximação, já tentada por Julius Bahnsen, por exemplo, não seja de todo inviável, de modo que, aqui, a sugiro. Com relação a Schelling, o caso parece ser ainda mais obscuro, pois a antipatia de Schopenhauer não é tão intensa quando se refere a ele em separado, pelo contrário. Que dizer da atitude de Schopenhauer em relação ao próprio Kant, criticando-o tão duramente em um lugar e, em outro, louvando-o pelo que, na verdade, se mostra como mérito seu?
} 
Deve-se notar, todavia, que, na visão de Schopenhauer, as Ideias não são abstraídas pelo sujeito como o são os conceitos, mas, pelo contrário, são percebidas diretamente nelas mesmas. Em suma, as Ideias parecem fazer mais sentido em seu sistema como "objetos abstratos" - objetos que não são espaço-temporais, que não se encontram em relação causal com coisa alguma, e que não foram abstraídos como um conceito, mas, ao invés disso, consistem no aspecto real, objetivo, essencial do mundo como representação enquanto percebido por um sujeito privado de vontade. O papel crucial que desempenham no sistema de Schopenhauer é o de que são os objetos de toda experiência estética - tanto do artista como do espectador - e sua percepção constitui um insight na natureza essencial do mundo fenomênico. (SHAPSHAY, 2012)

Além de a obscura distinção entre "objeto abstrato" e "conceito abstrato" não parecer justificada, por uma dupla razão - que objeto, para Schopenhauer, é sempre objeto de um intelecto ("privado de vontade" ou não) e que abstrato é sempre algo retirado de alguma intuição, portanto derivado, nunca original ou absoluto -, não se deve perder de vista que o caráter puro desse objeto - a Ideia - consiste em sua indistinção com relação ao sujeito que conhece, uma vez que a forma espaço (e, por conseguinte, a relação causal em geral) encontra-se suspensa. Sendo assim, não há qualquer material de que abstrair conceito, mas também não há abstração existente sem esse processo. A Ideia é inteligível a posteriori, seja a partir de um sentimento - o prazer estético -, seja na consideração dos processos da natureza, e a via epistêmica fracassa por não nos levar adiante no que concerne ao modo de ser das Ideais. Concordo, nesse ponto, com Cacciola (1994, p. 79-80) quando esclarece que "[n]a existência em si (Dasein-an-sich) não há processos, mas temos de pressupô-los necessariamente como uma tradução daquilo que é em-si, na linguagem do nosso intelecto intuitivo, já que o em-si permanece incompreensível para nós”. O tema certamente espinhoso da "pressuposição necessária" deverá nos ocupar adiante, sendo no momento mais pertinente mencionar a ênfase de Cacciola no que concerne ao fato de a pluralidade ser tal apenas para intelecto, encontrando sua razão de ser não na existência autônoma das Ideias, mas na “hipótese" - diz Cacciola (1994, p. 65) - do conflito interno da Vontade.

Cada grau ou Ideia está portanto fora do tempo e do espaço, "enquanto é coisa-em-si e por isso alheia à pluralidade". [...] é preciso lembrar que as manifestações da Vontade, ao serem graduais, só existem para o conhecimento, onde aparecem como pluralidade de Ideias, ao passo que cada grau, quando considerado apenas em relação aos seus exemplares, é tão uno e tão fora do tempo como a Vontade [...] mantendo-se assim uma posição contrária a qualquer hipótese reducionista que desse margem a uma "história natural" teleológica. (CACCIOLA, 1994, p. 59-60; grifo meu) 
Minha leitura das palavras de Shapshay pode soar exagerada, mas semelhante aferrar-se à compreensão epistêmica da Ideia como objeto inextenso simples, embora complexo, cuja intuição privilegiada é a de algo puramente real e objetivo, produz mais ruído do que esclarecimento. Schopenhauer recusa por completo uma suposta "objetividade do objeto", ou objeto-em-si. A objetidade da coisa que aparece em múltiplas formas espaço-temporais não é a coisa independente de um sujeito, mas seu ser-objetivo em geral que, como tal, genérico, não é espacialmente delimitado e, portanto, não pode constituir uma representação completa, material, mas meramente inteligível sob a simples forma do tempo. O sujeito "privado de vontade" de modo algum deixa de ser sujeito (tampouco vontade!); apenas se torna "quieto", ou seja, não-movido por aquilo que se lhe apresenta, de modo a como que "perder a autoconsciência" em um arrebatamento, entrar em êxtase - a vontade que ele ainda é, calada, não se afirmando, é como que provisoriamente negada, deixando o intelecto livre de seu domínio. Desse modo, antes de prosseguirmos, deve ser pontuado que: (1) a percepção direta da Ideia nela mesma diz respeito ao fato de que cada Ideia é contemplada isoladamente das demais, como uma totalidade compreensiva do grau de objetivação que representa; (2) sua independência com relação ao tempo se refere ao fenômeno temporal, o "quando" já sempre espacializado, enquanto que seu modo de representação se dá na forma do tempo puro, não espacializado, portanto, sem distância, permitindo a unidade (ou confusão) de sujeito e objeto; e (3) o "ser privado de vontade" é a condição na qual o querer não é movido por algo particular segundo o interesse, ou seja, a relação do querer subjetivo com um fim determinado.

Uma discussão mais demorada acerca dos pressupostos e consequências de uma interpretação como a de Shapshay nos desviaria sem proveito... Sublinhando que se trata de uma solução ad hoc, aqui exposta por sua similaridade com o tratamento dominantemente estético geralmente dado à questão, limito-me a enfatizar que a tentativa de solução do paradoxo existente na noção de universal individuado em uma pluralidade de universais não é tarefa para a abordagem epistêmica. Toda abordagem epistêmica se vê encerrada no princípio de razão, sempre relacional, escapando-lhe as distinções feitas há pouco em (1), (2) e (3). Pelo contrário, adianto que, tendo surgido o problema no Livro II, é na consideração do Livro IV que o mesmo ganha sua maior clareza e seu mais relevante desenvolvimento, ou seja, nas partes do MVR que são dedicadas à perspectiva do mundo como Vontade, sendo o conteúdo 
do Livro III, quanto a isso, mera transição, do mesmo modo que, aliás, a apresentação da essência das Ideias lhe serve como pré-requisito indispensável. ${ }^{6}$ Finalmente, a solução sugerida por Shapshay soa, antes, como um paralelo do Universal Concreto hegeliano, uma vez que, se temos em mente que as Ideais estão intimamente ligadas à progressão dos graus de objetivação da Vontade no mundo natural, devemos admitir que, em tal caso, sua essência se não, também, sua existência - deveria independer do sujeito cognoscente. Este, sim, é um problema cuja discussão nos desviaria do escopo do presente trabalho. Basta dizer, a esse respeito, que é precisamente esse tipo de dilema que tem pela frente quem pretenda se ater exclusivamente ao aspecto da Ideia relativo ao conhecimento objetivo, que termina por implicar o confronto com o determinismo inexorável do mundo natural e, portanto, ignorar que a determinação da Vontade em cada uma de suas objetidades é absolutamente livre. Também livre deve ser considerada a determinação da Ideia: "Em toda parte podemos fornecer um fundamento apenas das aparências mesmas, das coisas particulares, nunca da [V]ontade, nem da Ideia em que ela se objetiva adequadamente" (SCHOPENHAUER, 2015a, $\$ 29$, p. 189; grifo meu). ${ }^{7} \mathrm{Se}$, de fato, é possível estabelecer um paralelo com o pensamento de Hegel, como veremos, isso se dá sob outro aspecto, que não o da caracterização da Ideia, mas de seu papel na dinâmica da Natureza.

Devemos nos lembrar do que afirma Schopenhauer (2014, cap. 18, p. 300; cf. 2015b, p. 237), que "temos de aprender a compreender a natureza a partir de nós mesmos, e não a nós mesmos a partir da natureza". Sob esta luz, defendo que é a partir do mundo como Vontade que o papel da Ideia deve ganhar sentido mais autêntico e originário (não derivado, não relacional), não do mundo como representação, pois o fato de a Ideia poder ser conhecida diretamente não significa que é desse conhecimento que devemos partir, mas do modo de ser dessa coisa conhecida, encontrável em cada um de nós, cujo conhecimento permanece condicionado pela inteligência e seu respectivo grau. ${ }^{8}$ Isso pode soar como uma teoria

\footnotetext{
${ }^{6}$ Palavras do próprio autor ao término do último complemento ao Livro II: "Não preciso salientar o fato de que as considerações com que nós aqui concluímos o segundo livro apontam forçosamente para o grave tema do quarto. Na verdade, eles passariam diretamente para o quarto livro, se minha concepção arquitetônica não os tornasse necessários para o nosso terceiro livro, que fica entre eles com seu conteúdo sereno, que é uma segunda consideração do mundo como representação" (SCHOPENHAUER, 2014, cap. 28, p. 518; cf. 2015b, p. 432. Grifo meu.). A despeito de estar aí o autor referindo-se a outro assunto - a dor de viver pelo curto alcance dos esforços individuais -, como veremos, suas palavras se aplicam muito bem a essa pertinência original da questão da Ideia à perspectiva do mundo como Vontade.

${ }^{7}$ A Ideia se refere, evidentemente, à "representação no todo, o inteiro mundo intuitivo [...], o espelho da Vontade" (SCHOPENHAUER, 2015a, p. 191).

${ }^{8}$ V. SCHOPENHAUER, 2014, cap. 1, p. 56 (cf. 2015b, p. 14): "todo objeto, qualquer que seja sua origem, já como objeto, é sempre condicionado pelo sujeito, [ou seja, é essencialmente mera representação sua]" (tradução
} 
transcendente, mas é a partir da imanência que Schopenhauer chega à Ideia segundo a perspectiva do mundo como Vontade, estando perfeitamente de acordo com seu projeto filosófico a decifração do modo de ser do que aparece, ${ }^{9}$ ou seja, o ser como Vontade tal como reconhecido em nós humanos e daí estendido a toda a Natureza.

De fato, Schopenhauer chega a defender que o esforço da vida orgânica consiste em buscar, por meio de cada indivíduo, atingir a plena realização do tipo ideal da espécie - tema aprofundado apenas nos complementos ao Livro IV -, como se esse universal fosse seu fim determinado, e, em verdade, é sua causa final. Se é o que tem em mente Shapshay, ela não o expressa no referido texto, mas o embaraço daí decorrente é bastante claro. No intuito de superar esse embaraço é que deveremos saltar por cima da discussão estética, bem como da epistêmica, não por negligência, mas rumo ao seu fundo metafísico, ou, em sentido estrito, ontológico. Antes, porém, uma última observação.

Outra alternativa que me parece insuficiente é a de se hipostasiar a Ideia como uma terceira instância de realidade, que decididamente não é nem Vontade, tampouco representação como o "objeto abstrato" (ou ponte epistêmica) de Shapshay. Tal é a posição de Wicks (2017), para quem Schopenhauer ofereceria um esquema tríplice: o nível da Vontade como coisa-em-si, o nível das "Ideias platônicas" - a distinção universal sujeito/objeto -, e o nível das coisas individuais no tempo e espaço. Vê-se aí, mais uma vez, o predomínio da consideração epistêmica, agora produzindo um terceiro elemento que, como tal, antes complexifica do que esclarece o monismo schopenhaueriano. A solução da Díade Coisa-emSi/Fenômeno de modo algum parece requerer sua conversão em uma Tríade Coisa-em$\mathrm{Si} /$ Ideia/Fenômeno, e isso deve se tornar claro em minha exposição, a cuja parte positiva iremos agora adentrar. O "terceiro elemento" não é uma hipóstase, tampouco precisa ser reduzido a uma simples ponte heurística para o vislumbre do em-si. O que poderemos constatar é que, de fato, as Ideais admitem um duplo modo de consideração de seu ser, não apenas de sua intelecção, em direto paralelo com a Vontade de que a Ideia é objetidade imediata. Assim como a Vontade una se dá a ver como Matéria, se dá a inteligir como Ideia,

modificada). Embora esse trecho ainda se encontre no âmbito de discussão do Livro I, a contemplação da Ideia ela mesma não deve ser caracterizada como exceção - cf. Schopenhauer, 2015a, §34, p. 207 -, sendo pelo grau de inteligência requerido que Schopenhauer destaca a peculiaridade do gênio. A diferença desse objeto com relação aos demais está enraizada na ausência de relação com a vontade individual enquanto motivo, produzindo-se "pleno equilíbrio" entre sujeito e objeto. Ver, no MVR II, cap. 31: entre o gênio e o homem de ação, há uma diferença quantitativa de capacidade intelectual, de modo que, no primeiro, esta ultrapassa o necessário, fazendo-o perder-se na "intuição" estética.

${ }^{9}$ Considero este o elemento irrecusavelmente fenomenológico da filosofia schopenhaueriana. 
seja em geral, seja em particular segundo o princípio de individuação, à diferença que a Matéria em geral é abstraída das percepções produzidas no intelecto enquanto a Ideia, como passo a expor, determina toda matéria. ${ }^{10}$ Do mesmo modo, também a Vontade pode ser considerada em seu ser como indeterminada em si e determinada quando afirmada no mundo das aparências.

\section{“A Natureza não dá saltos"... ou \\ O problema das espécies fixas, ou da pluralidade das Ideias}

As Ideias não são um expediente supérfluo, mas com o propósito preciso de, nas palavras de Cacciola (1994, p. 59), “dar conta da diversidade das espécies na classificação biológica dos indivíduos" no contexto da doutrina da unidade da Vontade ao lado de sua constatada contradição interna como seu "caráter essencial tendo em vista o mundo como Representação" (1994, p. 67; grifo meu). Tampouco precisam ser tomadas como mero instrumento, ao modo de uma ponte epistêmica (ou mesmo metafísica) entre a coisa-em-si e o fenômeno. São "platônicas" enquanto prote paradigmata de toda a realidade, o que significa dizer que consistem em determinações livres da Vontade por ela mesma independentemente de circunstâncias fenomenais. Afinal, circunstâncias externas são antes obstáculos para efetivação do "tipo fundamental”, ou ideal da espécie. Acontece, portanto, que, na efetividade espaço-temporal, as manifestações devem seguir um lento processo e assumem, para tanto, pode-se dizer, configurações subalternas que concorrem em paralelo pela realização do tipo ideal originário.

Ao se determinar como um paradigma geral do que quer efetivar, a Vontade se manifesta segundo inúmeras tentativas nesse sentido, cada qual se utilizando do material "genético" os indivíduos são expostos no espaço e no tempo, nisso consistindo o esforço deflagrado para que cada qual atinja o tipo ideal. O que parece uma evolução, contudo, é uma gradação, e isso

\footnotetext{
${ }^{10}$ Os limites do presente artigo impedem o desenvolvimento da questão sobre a matéria em Schopenhauer. Mencionada aqui apenas a título comparativo, a matéria - também comparável ao em-si - será doravante referida apenas como o material, ou estofo, pelo qual a Vontade se torna visível em suas múltiplas configurações segundo as determinações das Ideias. Recomendo ao leitor o capítulo 24 do MVR II, dedicado ao tema da matéria.

${ }^{11}$ Em sentido lato, orgânico, mas também inorgânico, enquanto aquilo de que as novas configurações materiais lançam mão para sua própria realização, a saber, o material disponível.
} 
Schopenhauer deixa claro. Que sentido, então, pode ter sua reiterada recorrência ao princípio de que natura non facit saltus? A resposta está na surpreendente passagem do §27 do MVR I:

[Quando] muitas aparências da [V]ontade entram em conflito nos graus mais baixos de sua objetivação, portanto no reino inorgânico, quando cada aparência quer apoderar-se da matéria existente [vorhandenen Materie] servindo-se do fio condutor da causalidade; desse conflito emerge a aparência de uma Ideia mais elevada que [vence] [überwältig] todas as [precedentes mais imperfeitas], todavia, de uma tal maneira que permite que a essência destas continue a existir de um modo subordinado, mediante a absorção em si de um análogo delas; semelhante processo só é concebível pela identidade da [V]ontade que aparece em todas as Ideias e pelo seu esforço em vista de objetivações cada vez mais elevadas. (SCHOPENHAUER, 2015a, p. 168. Tradução modificada)

Com efeito, o modo de expressão não nos ajuda - que significado pode ter a afirmação de que a aparência de Ideia "emerge" (hervorgeht aus) de um conflito meramente fenomenal?! Por sua vez, a explicação do processo segundo a "identidade da Vontade" fornece a pista para a compreensão de que os graus aparentes consistem em manifestações do mesmo, como um desdobramento ao invés de um salto. Isso ainda soa estranho e, poder-se-ia dizer, "forçado", além de tendente a doutrinas evolutivas. Mas não se trata disso, certamente. Para compreendê-lo, considero útil destacar o que aí encontro de "surpreendente".

A passagem é antes de tudo surpreendente porque nos coloca diante de algo como a Aufhebung hegeliana, aplicada a caso inteiramente diverso. Não se trata aqui, certamente, de uma dialética do Espírito movendo-se historicamente segundo um fim preestabelecido, a Liberdade, o Saber Absoluto. ${ }^{12}$ Todavia, embora nos encontremos perante dois sistemas cujos solos são incompatíveis no geral, parece que, no particular, se tangenciam em virtude de um propósito comum. Nas palavras de Hösle (2007, p. 347), "Hegel não conhece nenhum desenvolvimento da natureza", tendo rejeitado "a concepção de uma evolução dos organismos (§249A, com suplemento, 9.31ss.; §339Z, 9.349) - plenamente de acordo com importantes

\footnotetext{
${ }^{12}$ A despeito disso, é digno de menção que também Cacciola, por caminhos diversos, teve sua atenção chamada para o trecho que venho de citar, encontrando aí a mesma possibilidade de aproximação. O fato de eu haver me deparado com isso de modo independente não dispensa o acréscimo dessa importante referência, muito pelo contrário. Em seu livro Schopenhauer e a questão do dogmatismo, Cacciola dedica algumas páginas no início do segundo capítulo, intitulado "A teleologia e a questão das causas finais", precisamente ao que chama "possível parentesco entre Schopenhauer e Hegel", chegando mesmo a se perguntar: "Se há uma oposição e o pensamento de uma harmonia na natureza, que estaria presente mesmo no conflito, por que não admitir um movimento dialético que levaria à conciliação dos opostos, tal como em Hegel?" (1994, p. 72). Trata-se mesmo de uma questão que não deve calar e que merece toda a atenção. Diferente de Cacciola, contudo, não persigo o problema da dialética - e, portanto, do movimento -, detendo-me antes no modo de ser da pluralidade das Ideias e sua resolução na unidade originária autocontraditória.
} 
biólogos de seu tempo (por exemplo, Cuvier)". ${ }^{13}$ É sabido que Schopenhauer estima, dentre outros, Cuvier ${ }^{14}$, contra doutrinas de cunho genealógico como a de Lamarck. É aceitável que, em tal contexto, Hegel e Schopenhauer coincidam na busca de alternativas para a dialética de Fichte, mas isso não autoriza deixar-se de lado a evidência de que estejam competindo no mesmo terreno, ou melhor, que Schopenhauer esteja jogando com as fichas postas na mesa da filosofia de seu tempo. A convergência não deve ser reduzida a mera coincidência, mas encarada seriamente como diálogo velado, implícito, mesmo que involuntário, questão que, no entanto, exige um estudo separado, impossível de se empreender no âmbito deste artigo.

Importante para o propósito atual é observar que o encadeamento necessário dos processos naturais não deve, seja para Schopenhauer, seja para Hegel, conduzir a um transformismo ou, posteriormente, a um evolucionismo, no qual se conserva o impasse acerca de alguns indivíduos de uma espécie evoluírem e outros não. Parece fácil, à primeira vista, incorrer no erro de vislumbrar no processo de aperfeiçoamento das manifestações da Vontade na Natureza uma doutrina evolutiva, mas a noção schopenhaueriana de Ideia vem justamente resgatar a doutrina aristotélica das espécies fixas. ${ }^{15}$ À luz do pensamento criacionista - em si mesmo incompatível com o aristotelismo, a despeito dos esforços da escolástica medieval platonizante -, uma doutrina como a das espécies fixas não implicaria sérios problemas, mas, filosoficamente, tende ao absurdo supor que as entidades naturais ou mesmo suas formas existam desde sempre por si mesmas e seu movimento se dê por causalidade interna, ou, dito aristotelicamente, mediante atualização de potências inerentes a cada substância. Trata-se de algo que a ciência do século XIX pretendia superar, apesar da dificuldade insuperável com relação ao surgimento da vida e do próprio átomo. Mesmo que assim fosse, como se explicaria, contudo, a aparente relação entre essas múltiplas espécies? O aferrar-se às aparências é o que teria levado os cientistas a tentar preencher lacunas em nome de suas teses transformistas, mas como, depois de Kant, admitir a precedência onto-lógica da realidade objetiva com relação ao sujeito do conhecimento para quem, exclusivamente, essa realidade existe? Em tal contexto, a independência absoluta das Ideias ou formas eternas das espécies pareceria um deus ex-machina, revertendo-se em vantagem para o transformismo a despeito

\footnotetext{
${ }^{13}$ Devo aqui agradecer a Federico Sanguinetti pela prévia indicação comentada desses passos no volume da Enciclopédia dedicado à Filosofia da Natureza. A propósito, vide o capítulo 2.1.2.b-c de seu livro La teoria hegeliana della senzazione (p. 92 et seq.).

${ }^{14}$ Bichat também deve ser incluído nesse grupo. V. RAND (2010, p. 37, n. 10).

15 Essa aproximação já fora vislumbrada, por exemplo, por Victor Goldschmidt, em seu "Schopenhauer, lecteur de Lamarck: le problème des causes finales”. Cf. CACCIOLA (1994, p. 93-94, n. 83).
} 
de todas as suas lacunas, mas talvez não seja o caso, como já dito acima, de considerar as Ideias dessa maneira, a saber, "realista". A tudo isso pretende responder a unidade da Vontade, seguida, portanto, pela unidade fundamental da Ideia considerada em si mesma, bem como da matéria em geral.

Um dos elementos que podem fazer supor uma proximidade entre o que disseram Schopenhauer e Darwin é exatamente o ponto a partir do qual divergem: que a progressão nos graus de manifestação do querer-viver se dá mediante a luta pela sobrevivência e conservação dos mais adaptados. Schopenhauer o diz, mas em sentido inteiramente diverso daquele que permeia a perspectiva empírica de Darwin. Schopenhauer, a propósito, enfatiza tratar-se de graus; cada grau ocupa posição distinta em relação a outro. Isso implica ruptura, sim, mas não no sentido de que não haja um elo intrínseco entre cada grau e suas manifestações colaterais, chegando mesmo a produzir zonas fronteiriças em que é custoso determinar onde termina o inorgânico e começa o orgânico, onde termina a vida vegetativa e começa a animal, e até mesmo em que ponto exato emerge o entendimento que tanto se sofistica na espécie humana, dotada, finalmente, da faculdade da razão. ${ }^{16}$ Acontece, todavia, que esse "elo", como um nexo causal - uma finalidade comum -, não é algo que se encontre no exterior, mas é, segundo as palavras citadas, "a absorção em si de um análogo", intrínseco à entidade superior, constituindo-a originariamente. Logo, a solução do elo exige não uma consideração empíricofisicalista, mas metafísica, ou seja, não submetida ao princípio de razão que exige das ciências positivas o nexo causal para dar conta dos processos naturais aparentes no mundo como representação.

Esse "elo" não é de modo algum aquilo que se possa procurar na exterioridade, como uma espécie ou mesmo um indivíduo híbrido de transição - Schopenhauer parece admiti-lo apenas no interior de uma mesma espécie, como caso particular de modificações determinadas pelo ambiente e circunstâncias externas, tais como aquelas que alteraram o biótipo humano em diferentes etnias, mas isso jamais explica a transição/transformação de uma espécie para/em outra. Esse elo, pelo contrário, é reconhecido naquilo mesmo que faz com que as espécies não surjam todas de uma vez, mas ordenadas cronologicamente (do ponto de vista

\footnotetext{
${ }^{16}$ No ensaio Sobre a visão e as cores, $\$ 10$, Schopenhauer (2003, p. 102-103) diz explicitamente o que entende pela expressão "Natura non facit saltus": "assim diz a lei da continuidade de todas as mudanças, em virtude da qual não ocorre na natureza qualquer transição de maneira totalmente abrupta [ganz abrupt], seja no espaço, no tempo ou em qualquer propriedade" (grifo meu). Essa "lei da continuidade" é reconhecida no livro VIII, capítulo 1, da História dos animais, de Aristóteles (2001, p. 635), onde se lê: "A Natureza avança pouco a pouco desde o inanimado até a vida animal de tal modo que é impossível determinar com exatidão o limite de demarcação, nem a que lado deveria pertencer um intermediário" (588 b 4-6).
} 
fenomenal objetivo, evidentemente, i.e. para um sujeito). O mesmo se vê em Hegel. Hösle (2007, p. 348) diz que, segundo Hegel, "faz parte do conceito de algumas (mas não de todas) entidades pressupor realmente outras", o que significa dizer que "animais, enquanto organismos heterótrofos, são impensáveis sem plantas, portanto as pressupõem também realmente; o mesmo vale para os carnívoros em relação a herbívoros”. Muito embora Schopenhauer não esteja levando em conta o "conceito" das entidades naturais e sua concepção de Ideia se distinga por completo da de Hegel, mantém-se que, em Schopenhauer, a Ideia de uma espécie pressupõe a Ideia das espécies de graus mais baixos, e assim deve ser do ponto de vista da causalidade natural representada enquanto modo pelo qual o intelecto, abstratamente, lhes confere sentido e reconhece em semelhante progresso uma unidade de fim. ${ }^{17}$ Schopenhauer, na seção subsequente, esclarece tudo isso de modo coeso, tornando ainda mais digna de nota essa inesperada convergência com Hegel que venho salientar.

A ideia de ser humano, para aparecer na sua atual significação, não podia expor-se isolada e separadamente, mas tinha de ser acompanhada por uma sequência decrescente de graus em meio a todas as figuras animais, passando pelo reino vegetal $\mathrm{e}$ indo até o inorgânico: todos esses reinos complementam-se para a objetivação plena da [V]ontade; a Ideia de ser humano os pressupõe, assim como as flores das árvores pressupõem folhas, ramos, tronco e raiz: os reinos da natureza formam uma pirâmide, cujo ápice é o ser humano. Para os que gostam de comparações, também se pode dizer que os aparecimentos desses reinos acompanham o do ser humano tão necessariamente quanto todas as inumeráveis gradações da penumbra acompanham a plena luz do dia ${ }^{18}$, e pelas quais esta se perde na escuridão; ou ainda se pode chamá-los ecos do ser humano e dizer: animais e plantas são as notas quinta e terceira descendentes do ser humano, enquanto o reino inorgânico é a sua oitava baixa. [...] Também encontramos aquela necessidade interior da gradação das aparências da [V]ontade, inseparável de sua objetidade adequada, expressa na totalidade delas por meio de uma necessidade exterior: justamente aquela em virtude da qual o ser humano

\footnotetext{
${ }^{17} \mathrm{O}$ problema do transformista seria assumir ingenuamente a aparência de um nexo causal naquilo que, em verdade, se dá por um salto qualitativo irredutível à lei do entendimento que não faz mais do que suprir a lacuna deixada. Vale ainda observar que esse "fim" é, para Schopenhauer, relativo ao impasse provocado pela luta por matéria, ou seja, não é um fim último, mas um querer-além superador inerente à insaciabilidade da Vontade sem limite. Desse modo, o impasse emerge como motivo/motor do querer-viver e sua efetivação se dá mediante a manifestação espaço-temporal de fenômenos de uma Ideia superior.

${ }^{18}$ Ver a penúltima nota. No mesmo contexto do referido ensaio de Schopenhauer, lemos na sequência sua teoria sobre a refração, segundo a qual, contra Newton, uma parte muito pequena toma direção distinta, "mas não rápido o bastante de modo que algo se separe e então, como que guardando uma lembrança do caminho recémabandonado, acompanhe a imagem principal sob a forma de imagem secundária" (SCHOPENHAUER, 2003, p. 103). Portanto, trata-se de variações do mesmo segundo condições materiais, pelas quais aparências diversas se veem intrinsecamente unidas, ao invés de serem independentes uma da outra. Note-se, todavia, que aqui se trata de uma Ideia/espécie particular considerada do ponto de vista de sua relação essencial com aquelas que se encontram nela pressupostas, justamente o que se explica pela unidade da Vontade que em cada Ideia se objetiva por inteiro, sem prejuízo das diferenças de grau e aparência.
} 
precisa dos animais para a sua conservação, e estes, por sua vez, precisam uns dos outros segundo os seus graus, e por fim também precisam das plantas, que por seu turno precisam do solo, da água, dos elementos químicos e seus compostos, do planeta, do Sol, da rotação e translação em torno deste, da obliquidade da eclíptica e assim por diante. (SCHOPENHAUER, 2015a, §28, p. 178-179)

Disso se depreende que, a despeito do fixismo das espécies, há um nexo não causal essencial em virtude da unidade da Vontade que a cada grau se objetiva de múltiplas maneiras, como em múltiplas vias pelas quais se empenha até atingir a aparência de um organismo capaz de consciência, a qual, sendo também consciência de si, reconhece a si mesma como culminância daquele empenho expresso no tempo desde milênios. Esse organismo último na ordem da Natureza - o humano - é o primeiro na ordem do conhecimento, conferindo razão de ser a todo o resto, por ele subjugado e ao mesmo tempo nele assimilado - o humano é um microcosmo que descobre, em sua própria possibilidade de existência, retrospectivamente, a Natureza como aquilo de que emerge. ${ }^{19}$ Portanto, o que aparece como nexo causal empírico é a aparência do nexo inteligível não causal entre as diferentes configurações do querer-viver assumidas na Natureza. Com efeito, a Natureza não dá saltos, mas cada Ideia é uma superação. Não significa, porém, que a existência efetiva de uma espécie exija sempre a coexistência do que lhe é inferior, mas que o que lhe é inferior lhe seja inerente em sua efetividade e com plena necessidade, podendo desde então até mesmo desaparecer. ${ }^{20}$ Mais do que isso, todavia, Hegel e Schopenhauer concordam em algo crucial para os propósitos desta exposição: "O animal, como qualquer outra coisa, na visão de Hegel, exibe alguma variedade da unidade e a sua função é existir como essa variedade da unidade. Enquanto coisa natural, a existência do animal é estendida espaço-temporalmente e, portanto,

\footnotetext{
19 Curioso observar que mesmo a narrativa bíblica da Criação expõe uma ordem necessária de obras que, certamente, devem servir como condições à existência humana: esta requer a dos animais "para seu serviço", por conseguinte das plantas para sua nutrição, estas das águas e terras secas etc. Apesar dos embaraços que semelhante doutrina evidentemente provoca, um filósofo tão remoto como Fílon de Alexandria (séc. I) já apontava para ela: "O mundo, diz Moisés, foi fabricado em seis dias; não que o Criador precisasse de uma certa duração de tempo, pois é verossímil que Deus faz tudo de uma só vez, bem como quando ordena e concebe, mas porque as coisas que nascem reclamam uma ordem. Ora, a ordem implica o número, e, em virtude das leis da natureza dos números, o mais próprio à geração [i.e., o mais perfeito] é o seis" (FÍLON DE ALEXANDRIA apud MORAES, 2017, p. 150). Mais adiante, Fílon (apud MORAES, p. 151) acrescenta que "tudo sendo constituído em bloco [homou], a ordem era, portanto, traçada, necessariamente, em uma relação inteligível, como modelo para a futura geração dos seres uns após os outros", o que pode ser interpretado como não consistindo em um processo, mas na expressão de "relações lógicas entre o todo e a parte ou entre o anterior e o posterior [...] segundo a ordem da prioridade lógica" (WOLFSON apud MORAES, 2017, p. 151).

${ }^{20}$ Esta é uma possibilidade cuja consideração deve ser retomada em outro momento da exposição.
} 
sua unidade deve ser efetivada [actualized] espacial-temporalmente" (RAND, 2010, p. 38) ${ }^{21}$. Por sua vez, a misteriosa "emersão" do que "emerge" - a aparência da "nova Ideia" - também pode ser interpretada como algo que "logicamente se segue" (hervorgeht aus) de outro algo dado. Nesse sentido, Cacciola, em nota, cita as relevantes considerações de Judithe Schlanger em seu livro Les métaphores de l'organisme:

Nada diz se essa ordenação dos seres, segundo um eixo de complexidade crescente, exprime uma evolução real ou uma classificação lógica; se se trata de uma gênese das espécies, umas a partir das outras no tempo, ou se há uma progressão apenas no sentido puramente plástico de uma disposição de formas já dadas, qualquer que tenha sido seu modo de aparição ou de constituição. ... A perspectiva lógica da evolução não implica necessariamente a perspectiva temporal do transformismo. (SCHLANGER apud CACCIOLA, 1994, p. 80, n. 46)

O paralelo possível aqui esboçado entre Hegel e Schopenhauer é justificável se se tem em vista o sentido íntimo da metafísica de cada um, que se exprime, em ambos os casos, na caracterização da contradição e da discórdia em sua originariedade. Tal consideração, como se deve perceber, não é ociosa, pois diz respeito diretamente ao modo de ser da Ideia una, espelho da Vontade, que se pluraliza em virtude de uma contradição interna encontrável no mundo das aparências, a qual, do ponto de vista da Vontade, é uma harmonia. Essa contradição, segundo Schopenhauer, que reiteradamente a expõe como sendo "da Vontade com ela mesma", enraíza-se precisamente na forma sob a qual se dá o conhecimento da Ideia: o tempo. ${ }^{22}$ Tanto Schopenhauer quanto Hegel - e não apenas este - detêm o mérito decisivo, inaugural para o pensamento contemporâneo, de repensar a contradição para além (ou aquém) de sua aplicação (como princípio lógico) às representações formais-conceituais conforme a herança clássica, algo até certo ponto sem precedentes na filosofia ocidental, ao menos se excetuarmos as correntes místicas. Se quanto a isso Schopenhauer passa despercebido, o mesmo não ocorre no que tange à contribuição hegeliana.

$\mathrm{Na}$ terceira aula de seu curso sobre "O princípio de fundamento", Heidegger (1999, p. 34) aponta como "essencial da metafísica de Hegel” a demonstração, na "Ciência da Lógica",

\footnotetext{
21 Tradução minha, modificada conforme texto original em inglês (p. 6).

22 Diz Schopenhauer (2015a, §33, p. 204-205): “todo ser no tempo é também um não ser: pois o tempo é precisamente aquele mediante o qual podem caber às mesmas coisas determinações contrárias: eis por que cada aparência no tempo também não o é: pois o que separa seu começo do seu fim é simplesmente tempo, [...] aqui denominado duração". Nesse sentido, também, a mesma Ideia manifesta-se na duração como sendo isto e como sendo outro, ainda que "ao mesmo tempo", segundo o espaço que ocupa e os nexos causais que determinam a existência de um e outro particular.
} 
de que "contradição e conflito não constituem um fundamento contra a possibilidade de qualquer coisa se efetivar", mas, "pelo contrário, a vida interior da efetividade do efetivo". Schopenhauer, por sua vez, escreve: a Natureza só existe em virtude desse conflito observável por toda parte. Citando em seguida uma referência de Aristóteles a Empédocles, Schopenhauer (2015a, §27, p. 171) acrescenta que "[t]al conflito, entretanto, é apenas a manifestação da discórdia essencial da [V]ontade consigo mesma”. Isso não significa, como por vezes se entende, uma recusa do princípio de contradição, mas uma consideração de que o mesmo é uma regra válida para as representações, não para as coisas elas mesmas. Nesse sentido, o próprio Kant falhara ao julgar, como os dogmáticos ${ }^{23}$, poder demonstrar a possibilidade de verdades de razão amparado naquele princípio, excluindo todo o resto do âmbito do pensável. A dialética hegeliana e a schopenhaueriana autodiscórdia da Vontade cumprem o papel de buscar superar o uso indevido das leis da representação para se pensar o em-si, constituindo respostas alternativas ao kantismo.

Estimando não ter sido supérflua essa digressão, retomemos o curso da exposição.

A chave para se compreender a pluralidade das Ideias reside na consideração de que, desde o grau mais baixo de objetivação, a Vontade, limitada nos fenômenos individuais, entra em luta consigo mesma por matéria. Nessa disputa, como no processo de nutrição, material orgânico e inorgânico alheio é suprimido e literalmente incorporado/assimilado ao próprio a fim de que este se mantenha em detrimento do outro. ${ }^{24}$ No conflito cego das forças, que se anulam reciprocamente, a Vontade tende ao travamento, quando, por exemplo, nenhum lado consegue prevalecer e, assim, encontra dificuldades para se conservar na existência. A saída do travamento exige um ato da Vontade que, sendo livre, liberta-se do travamento saltando para a possibilidade de um crescimento espontâneo. Esse salto, deve-se salientar, só é possível por liberdade, sem a qual a tensão de forças opostas equivalentes seria insolúvel; mediante o salto, pelo contrário, a espécie superior subordina a si as inferiores. Uma coesa e exemplar

\footnotetext{
${ }^{23}$ Em verdade, não apenas os dogmáticos. O que diz Leibniz sobre as verdades de razão é admitido por Hume no que concerne às relações de ideias nas ciências matemáticas. No que concordam céticos e dogmáticos? Que à razão pertence a prerrogativa de validar os objetos que lhe são próprios - o ceticismo radical que nega até mesmo essa possibilidade foi levado ao absurdo pelos idealistas e não chegou a ser levado a sério por céticos moderados. Pertence à crítica schopenhaueriana a Kant precisamente reprová-lo por lançar mão do princípio de contradição para validar a extensão de categorias do entendimento ao âmbito do meramente pensável. A suposição de ser a coisa-em-si pensável como causa do fenômeno (cf. CACCIOLA, 1994, p. 47 et passim) é o exemplo mais marcante de um uso ilegítimo e, portanto, dogmático, da razão, bem como um dos cruciais objetos da crítica schopenhaueriana ao pensamento kantiano que, nesse movimento, termina rompendo com seu dualismo. Sobre esta ruptura, v. Moraes (2013).

${ }^{24}$ Não me deterei, nesta oportunidade, nas evidentes consequências morais desse fato.
} 
abordagem desse impasse pode ser encontrada no início do $\$ 69$ do MVR I, em meio à questão do suicídio:

\begin{abstract}
Reconhecemos essa contradição nas aparências mais elementares da [V]ontade, na luta contínua de todas as exteriorizações das forças naturais e de todos os indivíduos orgânicos por matéria, tempo e espaço; vimos [no livro II] como esse conflito entra em cena aos poucos com distinção terrível nos graus ascendentes de objetivação da [V]ontade; ao fim, no grau mais elevado desta, a Ideia de [homem] [Idee des Menschen], esse conflito atinge o grau no qual não apenas os indivíduos que expõem a mesma Ideia se exterminam uns aos outros, mas o mesmo indivíduo declara guerra a si, e a veemência com a qual ele quer a vida e se revolta contra a travação da mesma, a saber, o sofrimento, o leva a destruir-se, de tal maneira que a vontade individual, mediante um ato volitivo, suprime o corpo, que é apenas a sua visibilidade, e isso antes que o sofrimento quebre a vontade. Precisamente porque o suicida não pode cessar de querer, cessa de viver, e a vontade afirma-se aqui justamente pela supressão de sua aparência, pois não pode mais afirmar-se de outro modo. (SCHOPENHAUER, 2015a, p. 462463)
\end{abstract}

Os micro-organismos mais rudimentares se multiplicam, crescendo em número enquanto cada indivíduo sucumbe por causas naturais. A suscetibilidade à destruição por causas externas exige aprimoramento da nutrição e da reprodução, sendo que o material existente é sempre a matéria-prima necessária à manifestação de uma nova espécie, o abandono de uma Ideia para o aparecimento de outra (SCHOPENHAUER, 2015a, §27, p. 171), que consiste em reiterada afirmação da Vontade para saída de seu autotravamento. (O mesmo se dá com o indivíduo humano, que, como Ideia singular, encontra o conflito no interior de sua própria espécie e, por extensão, em si mesmo, podendo vir a sair do autotravamento pelo suicídio, de maneira que o querer-viver que nele se afirma precariamente venha a se afirmar como outro indivíduo, quiçá mais capaz para a existência em outro contexto.) A autotrofia deve dar lugar à heterotrofia, isto é, a capacidade de produzir em si o próprio alimento à necessidade de encontrar alimento no meio em que vive, como já é necessário a certas plantas que se encontrem fora de seu habitat. A palavra "necessidade" não é aqui casual, pois envolve dependência do ambiente em virtude de uma carência interna, precisamente o que a cada vez uma nova Ideia procura superar. Animais nunca podem viver sem a destruição de matéria alheia, e aqui começa a luta propriamente dita, mais visível - não apenas mais sofrida, como sempre se salienta -, pela sobrevivência, cada qual somente sobrevivendo de material orgânico de que seus órgãos extraem também o inorgânico de que necessitam, como água e sais minerais. A cada grau de objetivação, portanto, a luta se 
intensifica, na medida em que o aperfeiçoamento das espécies não lhes oferece meios de sobreviver às próprias custas, pelo contrário, como se a vida jamais pudesse se libertar de suas origens, pois, segundo a metáfora baconiana, para que haja o dragão, a serpente precisa comer outra serpente $^{25}$. Na economia geral da Natureza, os graus inferiores são a cada passo submetidos por um maior número de usuários, diretos ou indiretos - isso, aliás, deve garantir, tragicamente, sua persistência na existência, ao menos quando a falta de um elo possa comprometer todo o resto ${ }^{26}$-, e o grau supremo, em contrapartida, acumula também o maior grau de sofrimento, pois objetiva o grau supremo do esforço pela vida e mais refinado (e sensível) sistema nervoso. A supressão de qualquer elo nessa cadeia alimentar pode trazer consequências imprevistas. Essa história é logo resumida por Schopenhauer nos seguintes termos:

\begin{abstract}
A Ideia mais perfeita, resultante dessa vitória sobre Ideias ou objetivações mais baixas da Vontade, ganha um caráter inteiramente novo, precisamente pelo fato de absorver em si, de cada uma das Ideias que foram dominadas, um análogo mais elevadamente potenciado: a [V]ontade objetiva-se em uma nova e distinta espécie: nasce, originariamente por generatio aquivoca, depois por assimilação no gérmen existente, seiva orgânica, planta, animal, ser humano. (SCHOPENHAUER, 2015a, §27, p. 169)
\end{abstract}

\footnotetext{
${ }^{25}$ Conforme a máxima empregada por Francis Bacon (Serpens nisi serpentem comederit non fit draco) e citada por Schopenhauer (2015a, §27, p. 169). V. tb. p. 170-172.

${ }^{26}$ Toda extinção é incapaz de impedir o movimento da Vontade na Natureza. Como a Ideia, irredutível a abstrações da razão, não pode ser delimitada em conceitos ou definições, é difícil dizer se há diferença entre uma espécie ser extinta "naturalmente", como se supõe ser o caso de dinossauros, ou pela ação degradante dos seres humanos ou qualquer fator de desequilíbrio no ecossistema. Schopenhauer, talvez recorrendo a um expediente ad hoc, chega a vincular extinções em massa em nosso planeta a mero exercício preparatório (Vorübung) da Natureza (SCHOPENHAUER, 2014, cap. 28, p. 509; 2015b, p. 424). De todo modo, pode-se perguntar que seria feito dessa Ideia particular, relativa a determinada espécie natural. Justamente por não termos uma definição exata da Ideia, não podemos concluir que aquilo que ela objetiva seja extirpado juntamente à espécie que a manifesta na Natureza em certo tempo-espaço. Vale considerar o que a certa altura diz Schopenhauer (2015b, cap. 22, p. 348. Tradução levemente modificada.): "ao lado da matéria [a mãe que tudo gera em seu ventre], temos de reconhecer a forma como uma espécie de pai das coisas, forma que, tão fugidia quanto a matéria é constante, [propriamente] muda a todo momento, e apenas pode conservar-se pelo tempo em que [se prende parasitariamente à] matéria (ora em uma parte, ora em outra), porém desaparece quando perde por completo esse ponto de apoio, como atestam os paleotérios e os ictiossauros". A inversão do platonismo é digna de nota, muito embora Schopenhauer esteja se referindo ao aspecto particular (morphe), não ao tipo eterno (idea), único (ídion). Logo começamos a perceber que, em última instância, trata-se de uma única objetidade da Vontade e, mais adiante, tomando o caso da espécie humana, pode-se oferecer uma saída para esse aparente dilema entre a eternidade de uma Ideia e a finitude de suas manifestações espaço-temporais que são eventualmente "abandonadas". Ao chegarmos a isso ganhará força uma observação a se fazer sobre os exemplos oferecidos por Schopenhauer aqui: a despeito de qualquer fator biológico acidental decorrente do contexto em que viviam paleotérios e ictiossauros, a similaridade de suas respectivas aparências às de antas e golfinhos modernos é claro indício de seu parentesco, por assim dizer, "metafísico".
} 
Mas veja-se bem que tudo isso pertence ao mundo fenomênico, isto é, à perspectiva da representação. Portanto, também aí (e somente aí) tem lugar a pluralidade das Ideias. "Por meio de tempo e espaço a Ideia se multiplica em inúmeras aparências", diz Schopenhauer (2015a, §26, p. 156; grifo meu) Ou seja, a pluralidade das Ideias já aparece, sim, segundo o principium individuationis. O que temos aqui, pois, é a sucessão das espécies no tempo. Não se trata de tentar ignorar que cada Ideia seja a universalidade atemporal de uma espécie. Objetidade imediata, com efeito, significa a essência atemporal de uma espécie, o tipo genérico segundo o qual nasce cada indivíduo particular, cada qual podendo se diversificar conforme as condições materiais de sua vida. Por sua vez, lê-se claramente que as Ideias se multiplicam e se sucedem no tempo (e também no espaço em que coexistem suas manifestações) a partir de uma luta que não tem nem pode ter "lugar" senão no mundo fenomênico, pois "tempo existe apenas para a aparência [...] e é sem significação para a força mesma” (SCHOPENHAUER, 2015a, §26, p. 159). Aqui parece se encontrar o perturbador paradoxo... Schopenhauer muito rapidamente nos conduz à tese da "identidade de toda a matéria" em nome da qual evoca a necessidade de uma regra (Regel) para o aparecer $e$ desaparecer dos fenômenos mediante a luta pela posse da mesma matéria (SCHOPENHAUER, 2015a, §26, p. 156). Por isso mesmo, todavia, prossegue Schopenhauer, não é ao mundo como representação que devemos nos ater! O \$28 do MVR I é o passo em que Schopenhauer, veementemente, recusa qualquer reducionismo da Ideia à multiplicidade de suas configurações, remetendo-a à coisa-em-si, à perspectiva do mundo como Vontade. Por uma questão de economia, mas remetendo o leitor ao todo do que é ali exposto, destaco o seguinte:

[...] visto que é a [V]ontade única e indivisa [...] que manifesta a si em toda a Ideia como se se manifestasse num ato, [...] o desdobramento da Ideia, em si simples, $[\ldots]$ na pluralidade de partes e estados do organismo, $[\ldots]$ na medida em que são causa e efeito, portanto meios e fins [...], não são essenciais e próprios à [V]ontade, à coisa em si mesma que aparece, mas apenas ao seu aparecimento no espaço, no tempo e na causalidade [...]. Pertencem, portanto, ao mundo como representação, não ao mundo como vontade; [...] [a] unidade originária da Ideia, [...] na aparência, assumiu a forma da pluralidade e da diferença. [...] porém, [...] deve-se excluir toda determinação temporal, pois a Ideia encontra-se exterior ao tempo. [...] [A Vontade] não conhece tempo algum, visto que a figura temporal do princípio de razão não pertence a ela, nem à sua objetidade originária, as Ideias, mas só à maneira como estas são conhecidas pelos indivíduos - eles mesmos transitórios -, isto é, pertence só às aparências das Ideias. (SCHOPENHAUER, 2015a, p. 182-183/185-186) 
Observe-se com cuidado os usos do singular e do plural. Nos complementos, lê-se ainda que, sendo o conhecimento "condicionado por pluralidade e diferença [...], o conhecimento e a pluralidade, ou individuação, mantêm-se e desfazem-se juntos, na medida em que se condicionam reciprocamente" (SCHOPENHAUER, 2015b, cap. 22, p. 332). Por isso mesmo, como disse acima, produzir em Schopenhauer uma Tríade, como faz Wicks, não ajuda, antes atrapalha. Não há dualismo em Schopenhauer, mas um duplo modo de consideração do mesmo. Por que um duplo modo? Porque a diferença é requerida pelo intelecto, incapaz de conceber a unidade absoluta, razão pela qual todo dizer de um "absoluto" não passa de discurso vazio. O "terceiro", a Ideia, apenas exprime a um só tempo a livre autodeterminação da Vontade, una e a mesma em cada uma de suas configurações assumidas, de um lado, e, de outro, a unidade originária de todo o mundo representado enquanto fenômeno da primeira. ${ }^{27}$

A solução para o impasse - tido por contrassenso - requer a consideração de que é para o homem que há semelhante sucessão das espécies na Natureza. Mais do que isso: que há para o homem semelhante pluralidade das Ideias.

O que aparece nas nuvens, nos riachos e nos cristais de gelo é o eco mais fraco daquela $[\mathrm{V}]$ ontade, que entra em cena mais completa na planta, mais completa ainda no animal e perfeitamente completa no ser humano. Mas apenas o que é essencial em todos os graus de objetivação da [V]ontade é o que constitui a Ideia: o desdobramento desta [...] é-lhe inessencial e reside somente no modo de conhecimento do indivíduo, tendo também realidade apenas para este. $\mathrm{O}$ mesmo vale necessariamente para o desdobramento da Ideia que é a objetidade mais completa da [V]ontade ${ }^{28}[\ldots]$ Para quem bem apreendeu isso e sabe distinguir a [V]ontade da Ideia e esta da sua aparência, os eventos do mundo [formas casuais do fenômeno da Ideia que não pertencem a ela] têm significação não em si e por si mesmos, mas só na

\footnotetext{
${ }^{27}$ Ao leitor que já pareça claro não se tratar de uma ponte epistêmica, contudo, pode persistir a questão se não seria mesmo uma ponte metafísica. Uma ponte deve tocar ambas as margens do abismo que transpõe, mas as passagens que venho de citar me parecem suficientes para mostrar não ser esse o caso, mas sim: o mundo, considerável sob uma dupla perspectiva, é ao mesmo tempo o todo das representações e o todo das livres afirmações da Vontade; nada sabemos do em-si nele mesmo, mas apenas em nós e a partir de nós. Nesse sentido, a própria consciência de si como vontade seria uma ponte metafísica com o mundo, não sendo isso uma prerrogativa da Ideia. Dito de outro modo, é como dizer que o em-si se objetiva imediatamente em nós e que a autoconsciência se dá por um sentimento assim como a Ideia se desvela à inteligência. Portanto, sentimento imediato é um correlato do puro conhecimento, ambos no âmbito da intimidade irrefletida, mas ambos passíveis de reflexão objetiva a posteriori, seja na consideração do próprio caráter empírico, seja na consideração dos processos naturais. Tudo isso parece já se colocar além do escopo do presente artigo, ficando aqui a título de pista a ser perseguida. Por ora, mantenhamo-nos no aspecto mais estrito a que esta exposição se delimita.

${ }^{28}$ Logo, Ideia e Vontade não formam um par, muito embora a distinção a seguir pareça justificar que haja não apenas uma díade, mas uma tríade. O que não se deve ignorar, todavia, é que se trata de graus universais (Ideais) e particulares (aparências) de expressão do mesmo (Vontade).
} 
medida em que são as letras a partir das quais se pode ler a Ideia de [homem]. (SCHOPENHAUER, 2015a, §35, p. 210-211)

Do ponto de vista da representação, o homem, conduzido pelo fio da causalidade, encontra pressuposta em sua própria existência a existência de tudo o que lhe terá precedido no mundo natural, e isso a título de justificativa, mas de uma justificativa fadada ao fracasso aos pés dos limites insuperáveis da etiologia. É justamente o encontro de seu dead-end nas assim-chamadas "forças da natureza" que dá ensejo para que Schopenhauer empreenda o salto para a metafísica, para a perspectiva do mundo como Vontade, reconhecendo naquelas, pela famosa analogia do querer/não-querer humano (SCHOPENHAUER, 2015a, §24, p. 144-147), a objetidade primitiva deste último. A noção de intelecto, ou melhor, sua existência, deve pressupor, como vimos, organismos mais simples, estes o inorgânico e assim até as forças da natureza. Por sua vez, toda essa gradação supõe o intelecto. ${ }^{29}$ A unidade da Vontade, imediatamente objetivada como Ideia única determinando e particularizando uma matéria em geral, reflete-se no conhecimento sob uma multiplicidade fenomenal que, embora múltipla, manifesta sempre o mesmo. ${ }^{30} \mathrm{Se}$, todavia, o então superado não desaparece em seu dar lugar ao grau mais elevado, é porque lhe permanece pressuposto ideal $e$ realmente, não apenas como condição de sua existência espaço-temporal, mas também como meio direto ou indireto de subsistência de algum elo na cadeia alimentar, por exemplo. O homem, desta feita, não apenas tem em si toda a "história natural", mas serve-se, direta ou indiretamente, da totalidade de suas configurações externas.

Em síntese, pode-se propor que o ponto de partida para toda a doutrina schopenhaueriana das Ideias é, nada mais, nada menos, do que a Ideia do homem, ou seja, a manifestação da Vontade em seu grau mais elevado, conforme referida mais acima. Isso deverá nos conduzir a uma elucidação acerca da diferença entre caráter inteligível e aquilo que aqui se denomina "Ideia do homem". Todavia, reservemos isso para depois a fim de que não se perca a ordem da exposição. Dando continuidade ao raciocínio, devemos observar que,

\footnotetext{
29 Aqui se reconhece o que Cacciola (1994, p. 77) refere como "paradoxo de Zeller", decorrente da não observância de que se trata de uma dupla perspectiva sobre o mundo: aquela realista que toma a Natureza como objeto independente do homem e aquela outra, crítica, que toma a Natureza como representação.

${ }^{30}$ As Ideias, graus, são como os momentos e lugares particulares em que o mesmo se manifesta de modo a que o próprio modo de ser do homem tenha lugar no tempo e no espaço. Cada espécie é como o tipo ideal que cada estágio se esforça por atingir, mas tudo isso se resolve em um único querer que, no homem, se torna capaz de conhecer a si mesmo como tal. A Ideia, então, manifesta no homem o sentido de sua existência e de seu modo de ser, como fica claro na citação do Livro III (\$35) do MVR I.
} 
para Schopenhauer, como para Hegel, a Natureza é ahistórica. ${ }^{31} \mathrm{O}$ que, então, se desenrola no suceder das espécies segundo o movimento da Vontade na Natureza é, também similarmente ao que diz Hegel, resultado da pressuposição real daquilo que é idealmente pressuposto na existência real/efetiva do sujeito que conhece. Isso não é possível para os animais, mesmo dotados de entendimento - o que faz deles sujeitos precários do conhecimento -, uma vez que, para eles, não haveria passado. Animais não têm história e, desse modo, não têm nada atrás si, senão pelo conhecimento humano. É o que permite a Schopenhauer dizer que, por meio do cérebro (ou intelecto, do ponto de vista subjetivo),

surge de um só golpe o mundo como representação com todas as suas formas: objeto e sujeito, tempo, pluralidade e causalidade. O mundo mostra agora o seu segundo lado. Até então pura e simples vontade, doravante é simultaneamente representação, objeto do sujeito que conhece. (SCHOPENHAUER, 2015a, §27, p. 175)

Pode-se disputar que esse mundo também existe para os animais, mas não supor que haja para eles uma genealogia de qualquer espécie. Pode-se disputar que, até então, há Vontade, mas não desconsiderar que se trata de uma Vontade ainda cega, enquanto tal sem objeto e, logo, alheia a toda objetividade em sentido estrito - dito de outro modo, o ser-objeto não se revelou para os animais desprovidos de autoconsciência e não há razão alguma para supor sua existência objetiva senão pelo e para o intelecto humano.

De fato, reconhecemos que a força interior da natureza, que originariamente é desprovida de conhecimento e impulsiona-se na escuridão, e que, quando atuou até alcançar a consciência de si, desvela-se como vontade, só atinge esse grau por meio da produção de um cérebro animal, e do conhecimento como função deste, instante a partir do qual surge nesse cérebro o fenômeno do mundo intuitivo. Ora, [mas] declarar esse mero fenômeno cerebral, junto com a legalidade que invariavelmente pertence a suas funções, como o próprio ser em si objetivo do mundo e das coisas nele existentes - ser em si que existe independente desse fenômeno, antes e depois dele - é manifestamente dar um salto [que] nada nos autoriza. [...] Precisamente porque o mundo se fez sem a ajuda do conhecimento, sua essência toda não entra no conhecimento, porém este pressupõe a existência do mundo, razão pela qual a origem do mundo não [se encontra] em seu domínio. (SCHOPENHAUER, 2015b, cap. 22, p. 346-347) ${ }^{32}$

\footnotetext{
${ }^{31}$ Não é à toa que Schopenhauer finalize o $\$ 35$ do MVR I dizendo que o "autoconhecimento [da Vontade] e, daí, a sua decisão pela afirmação ou negação [é] o único acontecimento em si". Aliás, Hegel estaria plenamente de acordo que apenas o que acontece por liberdade verdadeiramente acontece.

${ }^{32}$ Tradução levemente modificada. A argumentação, aqui, volta-se especialmente contra Fichte e sua doutrina acerca da faculdade de imaginação do Eu. Para o conhecimento haverá sempre um ponto cego relativo àquilo de
} 
Embora pareça à primeira vista paradoxal, como o parecera a Zeller, o fato de o mundo independer do conhecimento não significa que venha a ser independente de um sujeito cognoscente, já que só é conhecido e tem existência objetiva por representação; permanece insondável em seu estrito ser-em-si como tal não por existir objeto sem sujeito - na medida em que um objeto só pode ser representação de um intelecto -, mas como se se tratasse da impossibilidade de testemunhar um fato a que se esteve ausente - na medida em que o fenômeno da Natureza faz supor uma série de graus que antecedem o surgimento do intelecto no tempo e no espaço - e, por sua vez, o próprio fato só fizesse sentido por meio dessa testemunha - o sujeito que conhece o mundo natural. É o intelecto humano, com sua sofisticada capacidade de percorrer a série das causas - isso não é o mesmo que, pelo mero entendimento, intuir uma causa a partir de um efeito percebido ${ }^{33}$-, encontra no animal não apenas a condição formal de sua existência, mas também seu antepassado fenomenal. Por sua vez, esse intelecto só entra em ação na medida em que o entendimento lhe fornece um mundo objetivo como algo dado no exterior. Não caberia também aqui a citação de Suárez que Schopenhauer (2015a, §27, p. 177) transcreve em uma nota: “a causa final não move segundo sua existência real, mas segundo seu ser conhecido"? Não há contradição ou real paradoxo a não ser que ilegitimamente se coloque sob o mesmo ponto de vista perspectivas irredutíveis uma à outra. Que a problemática pluralidade das Ideias e sua sucessão temporal pode ser subsumida à unidade da Vontade, sempre a mesma em suas infinitas configurações no espaçotempo, de maneira que essa pluralidade de Ideias, em verdade, exprime uma pluralidade de atos da Vontade universal para sair de seus autotravamentos, é uma proposta sustentável pela seguinte afirmação:

[...] vemos na corporização inteira de um animal suas necessidades futuras, os seus objetivos futuros, antecipados pelos implementos orgânicos para a sua realização e satisfação [finalidade interna]. ${ }^{34}$ Disto resulta a aptidão

efetivo do qual ele não tomou parte alguma, mas isso, por sua vez, não significa que o conhecimento, visto desde o princípio de razão, não pressuponha graus de efetividade que condicionem sua própria efetivação.

33 “'.... no ser humano, a espontaneidade da atividade cerebral, que em última instância é decerto conferida pela vontade, vai além da mera intuição e da apreensão imediata das relações causais; a saber, vai até a formação de conceitos abstratos a partir daquelas intuições, e mais além até a operação com tais conceitos, isto é, até o pensar, no qual consiste a razão humana." (Idem, ibidem, p. 333-334).

${ }^{34}$ A resposta de Schopenhauer ao enigma da precedência do ovo ou da galinha é clara: a galinha. O bico da ave tem o único objetivo de romper o ovo. A ave precisa desse "órgão" em virtude da necessidade de romper a casca que deverá proteger sua existência contra predadores, mas que só poderá existir se a ave for provida dos meios para rompê-la. O ovo mesmo é um aprimoramento anterior que, nos répteis, já preserva do estágio larval vigente ainda nos anfíbios. Porém, o ovo é aprimorado por uma casca mais espessa no caso das aves, de maneira que o 
perfeita da estrutura de cada animal ao seu modo de vida, o que o equipa com as armas necessárias para que ele ataque a sua presa e afaste os seus inimigos, e o cálculo de todo o seu desenho e forma [jene Berechnung seiner ganzen Gestalt] em relação ao elemento e ao ambiente em que ele tem que aparecer como um perseguidor. [...] [A Vontade], como tal, permanece livre até mesmo das formas de conhecimento e, portanto, com referência a ela o tempo não tem significado, e, consequentemente, o futuro é tão próximo a ela como o presente. (SCHOPENHAUER, 2014, cap. 27, p. 503)

Importante destacar que, por meio de suas objetivações, a Vontade adquire de algum modo crescente conhecimento que lhe permite escapar a cada vez de seus travamentos, culminando nas possibilidades, contraditórias entre si, do já mencionado suicídio e da autonegação. Muito embora isso pareça uma solução ad hoc de Schopenhauer, deve-se concordar que está fora de nosso alcance compreender como isso se dê na matéria inorgânica, levando o filósofo a aderir à tese da generatio aequivoca, mas, por outro lado, sabe-se que a Natureza sem conhecimento, vez por outra, é bem-sucedida em se conservar mesmo sem semelhante auxílio. O que se constata até aqui é que a palavra de Schopenhauer oferece abundante e suficiente material para se superar o aparente paradoxo da pluralidade das Ideias e daquilo que daí decorre. Chegados aqui, devemos nos dirigir a implicações positivas para a compreensão de outros impasses, tais como, em primeiro lugar: Como é possível (acaso seja) a extinção do fenômeno de uma Ideia eterna? Afinal, como se sabe, a determinação de um novo querer implica sua entrada no tempo.

\section{Implicações para a tese da indestrutibilidade de nosso ser em si}

É sabido que, para Schopenhauer, a morte só atinge o fenômeno, que a própria vida é fenômeno. $\mathrm{O}$ que se pode dizer com relação à Ideia, de que o indivíduo é mera manifestação no tempo e no espaço? A essa altura, já se pode dizer que a Ideia não tem início no tempo e que suas determinidades só podem "se seguir" (hervorgehen) da luta interna da Vontade do ponto de vista da representação, segundo o qual a Natureza parece se desenvolver em suas múltiplas configurações. Resta, contudo, refletir sobre a possibilidade de extinção de uma "Ideia particular". Para tanto, sugiro a tematização do caso humano. Enquanto os animais

bico é requerido por esse tipo de ovo. Posteriormente, o bico pode vir a ser também um instrumento auxiliar de defesa e mesmo de ataque. Nos mamíferos há um aperfeiçoamento extraordinário, com precedente nos ovovivíparos, pois todo o desenvolvimento do feto se dá no interior do corpo da genitora, não mais ficando tão exposto às intempéries e perigos do mundo externo. Em verdade, nos mamíferos, além da maior proteção da nova vida em formação, deixa de existir o bico, tão inconveniente para a alimentação. 
ainda existem mais de acordo com a espécie do que segundo o caráter individual, com o ser humano se dá o inverso. Embora isso não seja o bastante para negar que os animais possuam caráter individual, a individualidade é tão marcada e clara no mundo humano que Schopenhauer chega a dizer que, nele, o caráter individual pode ser considerado como uma Ideia exclusiva. Sendo o indivíduo humano como uma espécie singular, seu caso é, logo, bastante elucidativo. Tal distinção deve facilitar a abordagem da questão que agora se coloca, pois a diversidade humana dá a aparência de progresso e renovação, ausentes nos animais, e, portanto, permite a suposição de que, na morte, o caráter individual, por ser agudamente determinado, também se extingue, o que, a princípio, parece não ocorrer ao caráter da espécie. Mas por que não concluir algo bem diferente desde que se esclareça a natureza da relação entre o caráter e a espécie e entre esta e a Ideia?

São diversas as ocasiões em que Schopenhauer insiste na insubstancialidade do indivíduo, o mesmo devendo valer para as espécies em suas respectivas particularidades. Aqui tratamos da possibilidade de extinção, que de fato acomete a um e outro fenômeno. No primeiro complemento ao MVR, porém, Schopenhauer parece dizer um pouco mais do que "a morte atinge apenas o fenômeno", declarando, em vez disso, que o "mundo objetivo, no qual tomamos lugar de acordo com o curso da natureza" - sempre segundo o princípio de razão depende de nós enquanto sujeitos do conhecimento, já que ele é nossa representação, e, por isso mesmo, o "mundo do qual me separo quando morro é [...] apenas minha representação [Die Welt, aus der ich durch den Tod scheide, war andererseits nur meine Vorstellung]" (SCHOPENHAUER, 2014, p. 58). ${ }^{35}$ Que é feito de meu ser, aí em jogo?

Pernin (1995, p. 82) chega a se dar conta do estreito vínculo entre a correspondência do caráter individual humano a uma Ideia exclusiva e a sua escolha amorosa, mas não desenvolve as consequências, muito embora se pergunte, na direção certa: tal escolha, "tão altamente individualizada e seletiva, [...] não prova que o próprio indivíduo humano é a manifestação de um ato singular da [V]ontade?"36. Se, de início, questionamos a restrição da discussão acerca da essência da Ideia ao âmbito epistêmico e dos temas do Livro III do MVR, apontando para a necessidade de destaque para o âmbito metafísico exposto no Livro II, vemos-nos agora justificados para incluir o Livro IV em nosso percurso, em especial o complemento sobre o amor sexual, ainda que as referências a ele sejam aqui apenas alusivas.

\footnotetext{
${ }^{35}$ V. tradução de Jair Barboza (SCHOPENHAUER, 2015b, p. 17).

${ }^{36} \mathrm{Em}$ verdade, a autora reproduz precisamente o que é dito pelo próprio Schopenhauer no $\$ 26$ do MVR I. O que é, entrementes, digno de nota é o fato de Pernin extraordinariamente trazer essa observação, feita como que en passant, para seu livro.
} 
Nesse sentido, devemos problematizar o que diz Pernin logo a seguir: "que o indivíduo perecível não pode ser considerado como uma [I]deia plena”. Mas será possível recusar ou pelo menos desconfiar do alcance dessa conclusão? Afinal, nenhum indivíduo perecível, enquanto tal, pode ser considerado Ideia, nem plena, nem parcial (i.e. modo particular de uma espécie), se admitimos que o ser "pleno" da Ideia é atemporal, universal e indivisível, não suas instâncias espaço-temporais, dilema já superado acima. De todo modo, o que pretendo pôr em questão é, finalmente: que implicação pode ter a mortalidade ou (se se preferir) a transitoriedade do fenômeno material para a eternidade de sua forma ideal (ou vice-versa!)? Mais acima, em uma nota, foi citado trecho do capítulo 22 do MVR II no qual Schopenhauer afirma a fugacidade da forma, mas também foi feita ali por mim a distinção entre a forma particular, determinada exteriormente por características herdadas - a aparência - e sua essência indestrutível - o ideal - que por esse material vem à visibilidade. Para esclarecer essa questão, é necessário comparar a Ideia de um indivíduo humano e a Ideia de sua espécie.

Aquilo a que me refiro como sendo a "Ideia de Homem", embora Schopenhauer enfatize o caráter individual, consiste no tipo da espécie, ou seja, a Ideia cujas uniões sexuais buscam efetivar no particular. Essa Ideia é evidentemente indestrutível, ao menos enquanto haja humanos sobre a terra. ${ }^{37}$ Mas esse expediente, a reprodução, é o que permite a conservação dos melhores genes, determinações das Ideias mais elevadas, que ainda não puderam se manifestar adequadamente combinados em um mesmo indivíduo. O que é desprezado vai sendo a cada vez descartado com a morte dos indivíduos fenomenais. Significaria isso a supressão absoluta de cada caráter inteligível, ou melhor, de suas configurações singulares como um todo?

$\mathrm{O}$ mesmo indivíduo não sobrevive à morte, mas sim a vontade. Pode-se entender que o mesmo caráter "sobreviva"? Certamente. O caráter inteligível não é apenas a forma mais individualizada de objetidade da Vontade, mas, antes de tudo, a Vontade tornada indivíduo, livremente autodeterminada. Vale observar, então, que, no indivíduo humano, Vontade e Ideia assumem os mesmos limites em sua entrada no tempo, muito embora isso também se dê de maneira mais e mais obscura à medida que se desce aos graus inferiores de objetivação. Significa dizer que, no indivíduo humano, o mesmo caráter inteligível não se vê replicado em diversos tempos e lugares, variando apenas no inessencial, como nos graus mais inferiores, mas ocupa uma duração e lugar determinados. Isto considerado, deve-se admitir que a

\footnotetext{
${ }^{37}$ Mais adiante (re)colocarei em questão o que pensar das espécies extintas.
} 
indestrutibilidade do ser-em-si vale para o caráter individual, isto é, para a Ideia manifesta em um indivíduo. O que, portanto, parece indiferente até mesmo no caso do animal irracional, não o é no caso do humano. Considerando que o "eu" não passa de uma abstração cujo conteúdo é a autoconsciência, apenas à primeira vista poderia surpreender o que é dito no item 10 do capítulo 19 do MVR II, cujo sentido é exatamente desvincular o caráter inteligível do caráter empírico, embora sem empregar essa terminologia:

Nosso verdadeiro si mesmo [Selbst], o núcleo do nosso ser é o [Das] que se encontra atrás disso [do Eu conhecedor, meramente relativo aos objetos que conhece] e nada conhece propriamente dizendo senão querer e não querer, estar satisfeito ou insatisfeito, com todas as modificações [daquilo, der Sache] que denominamos sentimentos, afetos e paixões. Eis aí o si mesmo [Das] que produz aquele outro; não dorme, quando o outro dorme, e também permanece intocado, enquanto aquele outro desaparece com a morte. (SCHOPENHAUER, 2015a, p. 289) ${ }^{38}$

Que é morte para a Vontade? Nada. Também nada para o caráter inteligível, que nada tem de pessoal nele mesmo. É comum interpretar que o que sobrevive à morte seja puramente impessoal, e isso é correto, mas tal não deve autorizar a interpretação de que o caráter dessa pessoa se extinga junto com sua consciência, pois de modo algum são o mesmo. Quando disse que essa questão deveria ser preferencialmente tratada tematizando o caráter humano foi porque isso não parece oferecer tão grandes dificuldades no que toca aos animais. No caso humano, a situação é de todo diversa. Sem o intelecto, perde-se a consciência e a memória, pois o ser-afetado do corpo não mais pode ser conhecido pelo sujeito e, desse modo, o mundo se apaga para ele. Não apenas a consciência, mas também a memória deve desaparecer, muito embora vinculada à vontade ${ }^{39}$. O mesmo caráter, pois, considerado como modelo de um indivíduo determinado no tempo e no espaço, não retorna, nem pode retornar, ao menos não nas mesmas condições, como a mesma pessoa, determinada fenomenalmente por causalidade (ou necessidade) externa, eficiente, mas começa do zero, podendo ser o mesmo por intermédio de outro. Nesse sentido é, com efeito, na prática, indiferente dizer que o indivíduo desaparece por completo ou que seu caráter retorna sendo outro, mas isso não vale para sua essência indestrutível, ou melhor, para seu tipo, ou Ideia. Schopenhauer, consequentemente,

\footnotetext{
${ }^{38}$ É notável que Schopenhauer empregue um pronome como Das, iniciado por maiúscula, para se referir ao caráter despersonalizado e em si mesmo não situado do Selbst.

${ }^{39}$ Sobre a memória como relacionada à vontade, em vez de faculdade intelectual, ver o item 6 do complemento "Sobre o primado da vontade na autoconsciência" (SCHOPENHAUER, 2014/2015b, cap. 19). A discussão ali presente tem fundamental implicação sobre o que diz o autor, em outro complemento, "Sobre a loucura".
} 
recusa a transmigração das almas, estimando essa doutrina como simples metáfora, mas $o$ que é alma?

\begin{abstract}
Os filósofos anteriores a Kant, com poucas exceções, abordaram do lado invertido a explanação do processo de nosso conhecimento. A saber, partiram de uma assim chamada alma, uma entidade [Wesen] cuja natureza íntima e função própria consistiria no pensar e, em verdade, particularmente no pensar abstrato com meros conceitos [...] [Mas, pelo contrário], no processo de conhecimento, o último produto dele, o pensamento abstrato, converteu-se no primeiro e originário, e dessa forma, como disse, aborda-se a coisa do lado invertido. - [...] segundo a minha exposição, o intelecto brota do organismo e por isso da vontade, portanto, sem esta não poderia existir [...]. (SCHOPENHAUER, 2015a, cap. 22, p. 334-335)
\end{abstract}

A alma não é uma entidade originária, mas uma entidade abstrata concebida como tendo uma função também derivada, sendo a posteriori vinculada à faculdade de conhecimento e personificada como a própria consciência, de modo relativamente justo, eu diria, na medida em que deve a isso sua "existência" no mundo objetivo. A verdade de um indivíduo é, por sua vez, seu caráter inteligível - dito melhor: o caráter pelo qual se é um indivíduo determinado. Com a morte, esse caráter não se extingue. O que vale para um indivíduo determinado no breve curso de sua vida deve valer para seu caráter indestrutível e imutável, no mundo humano tal como nos demais graus de objetivação da Vontade. Refiro-me à seguinte passagem: "Ora, assim como um mesmo tema pode ser exposto [em cem] variações, assim também o mesmo caráter pode expor-se [em cem] decursos de vida bem diferentes" (SCHOPENHAUER, 2015a, §28, p. 184. Tradução modificada). No Livro III, contudo, encontramos uma ilustração ainda mais eloquente, quando Schopenhauer (2015a, §35, p. 211212) compara o mundo às peças de Gozzi, nas quais, segundo ele, "entram em cena sempre as mesmas pessoas [Personen]", de maneira que, à parte diferentes motivos e acontecimentos, permanece o espírito, não sabendo as personagens de uma peça "o que se passa em outra, na qual elas próprias, não obstante, atuaram", "Pantaleão não se torna mais ágil ou generoso, nem Tartaglia mais escrupuloso, nem Brighella mais corajoso ou Colombina mais modesta", "para cada evento, para cada obra que foi abortada em gérmen, ainda permanece aberta a infinitude contínua de seu retorno". A extensão disso ao caráter individual considerado atemporamente do ponto de vista da Vontade traz consequências extremas.

É razoável que o leitor desconfie aqui de uma inconsistência, pois até então defendi que a pluralidade das Ideias - por conseguinte, dos caracteres - é meramente fenomenal, ainda 
que amparada formalmente. A isso respondo desde já que a determinação da Vontade é perene e incansável, que cada uma de suas determinações permanece como condição de avanço e que nenhuma vida particular pode chegar à plenitude de suas realizações, pois não há um fim último a atingir. Dito brevemente, nenhuma afirmação do querer-viver extingue-se em si mesma, apenas a aparência material em virtude de sua natureza. A própria Natureza, diz Schopenhauer (2014, cap. 28, p. 508), "[a] leva à destruição, logo que el[a] deixa de ser adequada para esse fim", a conservação da espécie, observada a ressalva para o caso do ser humano, cuja longevidade ultrapassa bastante a maturidade de sua "vida útil", i.e. sua capacidade reprodutora. Adicionalmente, é cabível admitir que a pluralidade de Ideias e caracteres participa de uma eternidade relativa, de modo a serem, como essências que são, indestrutíveis, uma vez que a multiplicidade fenomenal consiste na multiplicidade de instâncias do que é, na verdade, uma só Vontade, uma só objetidade. Tal eternidade é relativa por significar meramente, no modo privativo, a não-temporalidade daquilo que ultrapassa o princípio de razão (em que se enraíza toda temporalidade), mas não absoluta tal como se pode supor que seja em si mesma. Desse modo, faz sentido dizer que as livres determinidades da Vontade são eventos irrevogáveis como indestrutível é a Vontade mesma. Cada indivíduo é único, mas cada um pode ser tido como centenas de variações do mesmo caráter em centenas de tempos e lugares, e isso parece empiricamente corroborável. Por conseguinte, parece fora de alcance opor a tese contrária, de que cada determinidade individual da Vontade seja passível de extinção uma vez que, em si mesma, cada qual é atemporal. Uma vez determinada, a Vontade entra no tempo; se o indivíduo morre, ela deve conservar sempre essa determinação ressurgindo "de imediato" sob novo aspecto, em novo corpo, tempo e lugar, tão logo as condições fenomenais objetivas o permitam. Finalmente, pode-se dizer que desde sempre uma mesma Vontade, uma mesma Ideia, aguarda a oportunidade de se fazer visível em seu grau mais elevado, com a maior clareza. Não é disputável que a determinação da Vontade como simples Ideia seja de todo diversa de sua manifestação espaço-temporal. Considere-se, porém, que essa Ideia determinada deve para sempre, desde que encontra lugar no mundo, manifestar-se sempre mais uma vez, configurando uma espécie de "eterno retorno", como se usa reconhecer em Schopenhauer. Para que uma espécie seja extinta, é necessário que a Ideia não encontre matéria em que se manifestar: "Em relação aos indivíduos tão fugazes como a água do córrego, as [I]deias, por outro lado, são permanentes, como os 
redemoinhos, os quais apenas o esgotamento da própria água poderia destruir" (SCHOPENHAUER, 2014, cap. 28, p. 509).

Também para Hegel, nas palavras de Rand (2010, p. 49), “a espécie é dependente, para sua própria forma e formalidade, da efetivação particular que ela alcança no corpo do animal", pois "nenhuma forma de vida poderia ser a forma que ela é sem que fosse diferenciada de alguma outra forma de vida, cada espécie é a espécie que é ao realizar-se efetivamente como a forma das atividades dos corpos animais materiais unidos em e por meio dessas atividades". Que atividades seriam essas?

Hegel afirma que todas as atividades relevantes do animal com vistas à preservação da unidade devem ser elas mesmas entendidas como partes de uma atividade global de conservação da espécie. Não é, pois, o fato de um dado aparato anatômico ter uma estrutura ou característica específica que fornece à atividade deste mesmo aparato sua unidade final, mas sim, sua unidade com outros indivíduos através de uma relação ativa com eles. Esta relação é, no nível animal, sexual-reprodutiva, orientada no sentido da reprodução continuada da espécie mediante a contínua autorreposição dos indivíduos que a ela pertencem. (RAND, 2010, p. 48-49)

Torna-se coercitivo admitir que aquele caráter suprimido pela autonegação da Vontade, privado de consciência, portanto cego mais uma vez, deve retornar como "outra pessoa", em tempo e espaço distinto, como alguém que pode ser inteiramente diverso quanto a seu comportamento e aparência, mas não quanto a seu ser-em-si que aí se afirma uma vez mais, um caráter dotado a priori da possibilidade de conquistar a salvação. "Salvação", aliás, meramente pessoal - o caráter jamais poderia ser salvo, e, quiçá, por isso mesmo apenas se retira para o Nada, é suprimido junto ao mundo inteiro (de sua representação), que nada mais é do que a multiplicidade representada em sua consciência. Dito de outro modo, a salvação só é possível para o caráter empírico, ainda que graças ao inteligível.

O caráter empírico tem de fornecer num decurso de vida a imagem-cópia do caráter inteligível e não pode tomar outra direção a não ser aquela que permite a essência deste último. Mas semelhante determinação estende-se apenas ao essencial, não ao inessencial do decurso de vida que assim aparece. Ao inessencial pertence a determinação detalhada dos eventos e ações, que são o estofo no qual o caráter empírico se mostra. Tais eventos e ações são determinados por circunstâncias externas que fornecem os motivos aos quais o caráter reage em conformidade com a sua natureza.

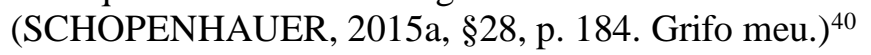

${ }^{40}$ V. tb. $\$ 26$, p. 161. 
Se pela negação da Vontade por ela mesma deve se extinguir o fenômeno do quererviver, o querer-viver ele mesmo até então afirmado, deixando de existir, não deixa de ser. Tal consequência, extraída exclusivamente da tentativa de se levar ao limite a doutrina das Ideias, parece ter sido habilmente evitada por Schopenhauer em nome da perspectiva de uma redenção do mundo, como se não fosse necessário concluir que o mundo fenomênico, na negação da coisa-em-si por ela mesma, só se apaga a partir uma de suas luzes. Para essa vontade que se nega, recai o manto do Nada. Cega, resgata sua liberdade e, com ela, a ingênua inconsciência do mal que inflige a si mesma em toda parte em que ainda é capaz de se ver. A solução que torna essa observação necessária, ainda que de início possa ter parecido alheia, é que por ela se supera o paradoxo da extinguibilidade de uma Ideia. Schopenhauer (2014, cap. 28, p. 509) arrisca dizer que o conflito na Natureza sugere, objetivamente, que "a sua única preocupação agora seria que nenhuma dessas belas invenções [Einfälle] [e combinações de Ideias] pudesse ser perdida, [...] desaparecer do tempo e da série causal". Daí, o mundo humano é sempre o mesmo, pois os caracteres não se renovam, mas sempre retornam, modificando-se apenas as circunstâncias particulares em que se manifestam empiricamente, encontrando ou não as condições propícias à negação da Vontade. Se o mundo se desenvolve, isto se dá em virtude do conhecimento acumulado, que também contribui para o refinamento dos costumes, dos aparatos e, portanto, renovação/reinvenção dos motivos. No fundo, a Ideia é única enquanto "objetidade de uma única e indivisa [V]ontade", relacionando-se "com todas as outras como a harmonia com as vozes isoladas" (SCHOPENHAUER, 2015a, §28, p. 183).

Ainda focados no caso do humano, seria correto dizer que se trate hoje de manifestação de Ideia essencialmente distinta daquela manifestada outrora, por exemplo, pelos hominídeos ora extintos? Ou será mais correto entender que, com o desenvolvimento do intelecto e do material genético, a mesmíssima Ideia haja encontrado novos modos de expressão de seu tipo atemporal? Na milenar disputa por matéria, o homem moderno não é tanto um novo passo na cadeia evolutiva, mas o aprimoramento da aparência daquele grau de objetivação que desde o começo tinha, por essência, o papel de submeter todos os demais os incluindo em si. De acordo com essa hipótese, as modificações morfológicas, fisiológicas, psíquicas e demais pertenceriam ao inessencial e, se isto está correto - impossível dizer, é verdade -, jamais se poderá encontrar o "elo perdido" que preencha a lacuna do salto qualitativo aí empreendido. 


\section{Um impasse final sobre a relação entre Ideia e temporalidade - à guisa de conclusão}

Ao buscar solução para os problemas mais comumente levantados sobre a doutrina schopenhaueriana das Ideias, uma hipótese implicitamente surgiu e poderia ser formulada por meio da seguinte questão: Serão todas as Ideias implicadas na Ideia de homem? A resposta dada, afirmativa, traz consigo uma decisiva solução para o problema da pluralidade das Ideias. Apenas para o homem há história, passado e futuro. Alternativas a essa hipótese parecem insatisfatórias por aquilo que delas decorre: ou que as Ideias teriam de progredir no tempo ou que o grau de objetivação mais perfeito da Vontade já se encontraria desde a eternidade como um telos absoluto para todo o progresso da natureza, quiçá para seu progresso moral. Pelo contrário, não se reconhece um progresso objetivo, mas uma objetivação retrospectiva cuja representação responde pelo lugar do humano na Natureza.

Nesse caso, a pluralidade das Ideias, de fato, seria requerida por nosso modo de conhecimento, uma vez que, sob o princípio de individuação e, sobretudo, segundo o princípio de razão suficiente, a unidade da Vontade, bem como a unidade radical da Ideia já enquanto ser-objeto em geral, se vê fragmentada em um sem-número de espécies vivas, elementos inorgânicos e forças naturais cuja síntese se revela incorporada no próprio ser humano. Uma mesma Vontade se afirma independente do tempo e sua objetidade imediata a representa de modo uniforme por toda parte desde sempre. Não temos aí, todavia, um universal dos universais, a escada e seus degraus, mas a objetidade imediata como tal, a forma de todo querer existir em geral e suas possibilidades determinadas apreensíveis por um intelecto como essências particulares. Desse modo, temos, de um lado, a mesma Ideia segundo a perspectiva do mundo como Vontade e, de outro, uma refração segundo a perspectiva do mundo como representação. Apenas a eternidade da primeira pode ser autêntica, na condição de originária determinação de toda afirmação possível (até onde se pode apreender) da Vontade, incognoscível nela mesma, objetidade meramente inteligível como ser-objeto em geral; já a segunda possui uma eternidade subalterna, relativa à existência de fato dos entes (vontades individuadas) cujo ser-em-si resta indestrutível. Embora o ajuste pareça modesto com relação ao que diz Shapshay, citada de início, ressignifica seu duplo modo de consideração na medida em que relativiza sua pertença plena ao mundo como representação e resgata a via metafísica para aquilo que fora reduzido inteiramente à via epistêmica com sua hipóstase de escadas e degraus. 
Esta exposição se anunciou "preliminar" no sentido de se pretender como ponto de partida para qualquer outra consideração de natureza epistêmica ou estética, mas também pelo tanto que, em suas aquisições, deixa por pensar. Antes de ser tomada como pretensiosa, deve ser encarada como chave de leitura a ser testada em suas implicações aqui inexploradas. Por que, por exemplo, supor a Ideia em vez de simplesmente afirmar que a Vontade se determina diretamente como fenômeno visível? Porque a Ideia é o correlato finito da Vontade absolutamente indeterminada, talvez, finitude iniludível em qualquer espécie de conhecimento, seja empírico ou estético. Em todo caso, discutir o papel da Ideia segundo seu modo de ser em vez de seu modo de cognoscibilidade não deve ter seu sentido confundido com o de uma questão transcendente semelhante a "Por que Ideias?". Cabe apenas perguntar: Que são Ideias? As Ideais emergem para o sujeito do conhecimento à luz de uma finalidade universal da Natureza e seus graus de expressão, como determinidade indestrutível de que participa tudo aquilo que existe enquanto existe, daí recebendo seu lugar-tenente na metafísica de Schopenhauer. Mais, por ora, não posso dizer, senão recordar o embaraço que de outro modo a noção de "fins da Natureza" pode causar em uma filosofia como a schopenhaueriana. Trata-se, afinal, de uma questão de honra ao pensador ir o mais longe possível em suas teses em busca de sua unidade - ao menos quando esta é por ele pretendida - ao invés de ater-se a denúncias acerca do que parece contraditório sem maior reflexão.

A rigor, nada sabemos nem podemos saber de eternidade alguma. A atemporalidade é negativamente determinada e o conhecimento que mais se lhe aproxima ainda se encontra sob a forma do tempo, em um estado de êxtase, de inconsciência, de arrebatamento, do qual só se pode guardar um obscuro sentimento que o artista procura traduzir na obra. Desse modo admito -, toda eternidade é relativa ao mundo como representação e, por conseguinte, a sugestão de um duplo modo de consideração da eternidade, uma autêntica e outra subalterna, não tem mais do que uma função, por assim dizer, didática, comparativa, pela qual se pretende expor a Ideia não como um terceiro elemento ou ponte entre dois outros. Antes, como inteligibilidade do essencial - Ideia atemporal com relação a toda pluralidade, relativa à multiplicidade de espécies ou graus - e, paralelamente, como condição formal de possibilidade de cada efetividade particular - Ideias atemporais com relação às aparências particulares de cada espécie de que são paradigmas, ou seja, primeiro como objetidade do emsi em geral, segundo, como tipo ideal dos seres naturais que o querer-viver quer efetivar. Um legítimo terceiro duplicaria na verdade nosso problema, produzindo dois abismos onde antes 
havia um. Uma ponte é um artifício que pode ser relativamente útil para a via epistêmica na condição de oferecer a inteligibilidade do em-si no fenômeno sensível, mas é uma impropriedade do ponto de vista estritamente metafísico-ontológico. A Idea é nela mesma um $S a t z$ - como tal, um salto por sobre o abismo, o princípio formal da realidade concreta como um todo, a visibilidade da coisa-em-si na pura inteligência, o princípio de toda singularidade, sendo como salto que ela se determina a cada vez. Satz dispensa pontes, progressões pretender o contrário é tentar dar fundamento ao infundado, ao passo que a Ideia é Ideia do que se determina no mundo, para aquém do que a coisa-em-si possa ser nela mesma em sua transcendência. Satz vom Grund - o princípio de fundamento/razão é o salto do fundamento, o fundamento saltado para a metafísica.

O que se deve, então, é aplicar à Ideia o duplo modo de consideração do mundo, tal como nos é possível fazê-lo, sem deixar perder o mais importante: não se trata de dois mundos, mas dois lados de uma mesma moeda. Desta moeda, porém, o lado oculto só se deixa ver através de um espelho. Isso porque a "moeda do mundo" gira conosco, sempre de frente para nós, o sujeito do conhecimento, como em um jogo de esconder... A "revolução copernicana" significa a inviolabilidade do lado escuro da lua.

\section{Referências bibliográficas}

ARISTÓTELES. Historia animalium. Trad. para o inglês por D'Arcy Wentworth Thompson. The Basic Works of Aristotle. Ed. Richard McKeon. New York: Modern Library, 2001. p. 631-640.

CACCIOLA, M. L. M. e O. Schopenhauer e a questão do dogmatismo. São Paulo: EDUSP, 1994.

HEIDEGGER, M. O princípio do fundamento. Trad. Jorge Telles Menezes. Lisboa: Instituto Piaget, 1999.

HÖSLE, V. O sistema de Hegel: o idealismo da subjetividade e o problema da intersubjetividade. São Paulo: Loyola, 2007.

MORAES, D. O dualismo kantiano e sua crítica por Schopenhauer: considerações acerca do caráter analógico da filosofia prática e suas limitações. Princípios: revista de filosofia Publicação do Programa de Pós-Graduação em Filosofia da UFRN. Natal, v. 20, n. 33, jan.jun. 2013, p. 411-447. Disponível em: <

https://periodicos.ufrn.br/principios/article/view/7525/5595 >. Acesso em: 15 set. 2017. 
MORAES, D. O logos em Fílon de Alexandria: a fronteira entre o pensamento grego e o pensamento cristão nas origens da teologia bíblica. Natal: EDUFRN, 2017. Disponível em: < https://repositorio.ufrn.br/jspui/handle/123456789/23984 >. Acesso em: 31 jan. 2018.

PERNIN, M.-J. Schopenhauer: decifrando o enigma do mundo. Rio de Janeiro: J. Zahar, 1995.

RAND, S. Subjetividade animal e o sistema nervoso na Filosofia da Natureza de Hegel. Trad. Verrah Chamma. Revista Eletrônica Estudos Hegelianos. Rio de Janeiro, v. 7, n. 12, jan.-jun. 2010, p. 32-51. Disponível em: <

http://ojs.hegelbrasil.org/index.php/reh/article/view/42/37 >. Acesso em: 15 set. 2017.

Original em inglês: Animal subjectivity and the nervous system in Hegel's Philosophy of Nature. Disponível em: <

https://www.academia.edu/797764/Animal_Subjectivity_and_the_Nervous_System_in_Hegel s_Philosophy_of_Nature >.

ROGER, A. Vocabulário de Schopenhauer. São Paulo: M. Fontes, 2013.

SANGUINETTI, F. La teoria hegeliana della sensazione. Trento: Verifiche, 2015.

SHAPSHAY, S. Schopenhauer's Aesthetics. In: ZALTA, Edward N. (Ed.). The Stanford Encyclopedia of Philosophy. Summer 2012 Edition. Disponível em:

< https://plato.stanford.edu/archives/sum2012/entries/schopenhauer-aesthetics/ >. Acesso em: 15 set. 2017.

SCHOPENHAUER, A. Sämmtliche Werke. Ed. Julius Frauenstädt. Leipzig: Brockhaus, 1877. $6 \mathrm{v}$.

SCHOPENHAUER, A. Sobre a visão e as cores. Trad. Erlon José Paschoal. São Paulo: Nova Alexandria, 2003.

SCHOPENHAUER, A. O mundo como vontade e representação: tomo II - complementos. Trad. Eduardo Ribeiro da Fonseca. Curitiba: UFPR, 2014. v. 1.

SCHOPENHAUER, A. O mundo como vontade e como representação: tomo I. Trad. Jair Barboza. 2. ed. rev. São Paulo: UNESP, 2015a.

SCHOPENHAUER, A. O mundo como vontade e como representação: tomo II. Trad. Jair Barboza. São Paulo: UNESP, 2015 b.

WICKS, R. Arthur Schopenhauer. In: ZALTA, Edward N. (Ed.). The Stanford Encyclopedia of Philosophy. Summer 2017 Edition. Disponível em:

< https://plato.stanford.edu/archives/sum2017/entries/schopenhauer/ >. Acesso em: 15 set. 2017. 